\title{
Old statues, new meanings. Literary, epigraphic and archaeological evidence for Christian reidentification of statuary
}

\begin{abstract}
This article examines literary, epigraphic and archaeological evidence for the Christian reidentification of statuary and reliefs as biblical scenes and protagonists, saints and angels. It argues that Christian identifications were promulgated, amongst others by local bishops, to make sense of imagery of which the original identity had been lost and/or was no longer meaningful. Three conditions for a new identification are discussed: the absence of an epigraphic label, geographical and/or chronological distance separating the statue from its original context of display, and the presence of a specific attribute or characteristic that could become the prompt for reidentification. In their manipulation and modernization of older statuary, Christians showed a much greater appreciation of the statuary medium than generally assumed.
\end{abstract}

\footnotetext{
Adresse: Dr. Ine Jacobs, The Ioannou Centre for Classical and Byzantine Studies, Oxford University, 66 St. Giles', Oxford OX1 3LU, UNITED KINGDom; ine.jacobs@classics.ox.ac.uk
}

The statues on display in the Constantinopolitan cityscape after Antiquity came to be surrounded by stories, urban legends and folklore. Moreover, the Parastaseis syntomoi chronikai and the ensuing Patria Konstantinupoleos make it clear that some of these statues were identified in interesting manners by the eighth and late tenth century respectively. ${ }^{1}$ In addition to or instead of the gods, heroes,

Versions of this paper were presented at the University of Warsaw, the University of Birmingham, the University of Oxford and the Universität Bern. I am grateful to Hugh Jeffery, Panayiotis Panayides, Efthymios Rizos, Grace Stafford and Mary Whitby for their feedback on an earlier draft. I would like to thank in particular Ben Anderson for his insightful comments, as well as the anonymous reviewers. All errors are my own.

1 The reception of statuary in both collections has been studied in manifold publications, including but not limited to: C. MANGo, Antique statuary and the byzantine beholder. DOP 17 (1963), 55-75; G. DAgron, Constantinople imaginaire. Études sur le recueil des "Patria". Paris 1984; S. BASSETT, The urban image of late antique Constantinople. Cambridge 2004; B. Anderson, Classified knowledge: the epistemology of statuary in the Parastaseis syntomoi 
or mythological personae that they initially were intended to depict, contemporaries also saw them as Byzantine emperors and Christian protagonists. Modern research has often been successful in finding out the originally intended identity of these and other statues, despite the occasionally 'misguided opinions' of younger eras. The originally intended viewing of a statue remains the focus of attention especially for archaeologists, despite the growing body of research on alterations, reinterpretations and repurposing. ${ }^{2}$ Attempts to trace, let alone engage with, alternative identifications or radically new takes arising in late antique and Byzantine centuries, have been few and are largely limited to Constantinople. ${ }^{3}$

This article focusses on statues that were given identifications entirely different to the ones they originally had, and on the ways in which such new identifications came about. Although the complicated phenomenon of statuary reception throughout time cannot be captured in monocausal explanations, I aim to demonstrate that reidentification was common and, even when explicit literary or epigraphic sources are not available, cannot be neglected if we want to understand the importance of statues in the centuries after their production. I will focus in particular on statues and reliefs that were reidentified as Christian

chronikai. BMGS 35 (2011), 1-19. Of both the Parastaseis and the Patria translations are available: A. CAmeron / J. Herrin, Constantinople in the early eighth century: the Parastaseis syntomoi chronikai. Leiden 1984; and A. BERGER, Accounts of medieval Constantinople: The Patria. Dumbarton Oaks medieval library, 24. Cambridge, MA/London 2013.

2 Research on the complete 'biographies' of statues, but also buildings and inscriptions has only very recently significantly progressed. See for instance the studies collected in D.Y. NG / M. SwetnAm-Burland (eds.), Reuse and renovation in Roman material culture. Cambridge 2018; A.M. Sitz, Beyond spolia: a new approach to old inscriptions in late antique Anatolia. AJA 123 (2019), 643-674, and S. A. Rous, Reset in stone. Memory and reuse in ancient Athens. Wisconsin 2019.

3 Examples from the capital are mentioned in MANGo, Antique statuary (as footnote 1 above), and especially BASSETt, Urban image (as footnote 1 above). See also R.M. DAwkins, Antique statues in medieval Constantinople. Folklore 35 (1924), 209-248, on 214-215. The possibility of reidentification is briefly touched upon in T.M. KRISTENSEN, The life histories of Roman statuary and some aspects of sculptural spoliation in late antiquity, in S. Altekamp/C. MarcksJacobs/ P. Seiler (eds.), Perspektiven der Spolienforschung 1. Spoliierung und Transposition. Berlin/Boston 2013, 23-46, see 34-35. A small number of case-studies of Byzantine monuments incorporating older reliefs viewed in alternative ways exists but by themselves do little to illuminate the wider phenomenon. See for instance B. KIILERICH, Making sense of the spolia in the little Metropolis in Athens. Arte Medievale N.S. 4/2 (2005), 95 - 114 and G. SANDERs, William of Moerbeke's church at Merbaka. The use of ancient spolia to make personal and political statements. Hesperia 84 (2015), 583-626, in particular 604-607, 613 with references to older literature). The most complete case-study is D. KINNEY, The horse, the king and the cuckoo: medieval narrations of the statue of Marcus Aurelius. Word \& Image 18 (2002), 372-398. 
scenes and protagonists, saints, biblical personae and angels, since the misconception that such three-dimensional imagery did not exist is a persistent one. ${ }^{4}$ Using a combination of literary, epigraphic and material sources, I will contend that allocations of alternative Christian identities were a regular occurrence already in Late Antiquity for which there is evidence also outside of Constantinople. After brief overviews on newly carved Christian statues and reliefs and the overall presence of statuary in Late Antiquity, I will focus on the earliest phase of Christian reidentification in the age of Constantine. Subsequent sections will explore various elements that led to a new identity being assigned and made permanent. I will argue that reidentifications, Christian or otherwise, should not be considered as cases of mistaken identity, but as positive and often conscious choices to make sense of imagery of which the original intention had been lost and/or was no longer meaningful. ${ }^{5}$ I will suggest that new identities were purposely assigned by specific individuals in society. Although physical remains will occur occasionally in these earliest sections, the focus will eventually shift to material evidence and archaeology. Starting with a case-study of a radically different Christian identity being assigned to images of Ares and Athena at Sagalassos, I will examine the characteristics of statuary for which new Christian identifications could help explain why they are preserved up until today.

\section{Christians and statuary}

Christians apparently were not taken by the medium of statuary. Protests first pertained to idols, but later extended to other pagan-mythological and also honorific statues. ${ }^{6}$ Christian suspicion towards and the resulting reluctance to con-

4 Such reidentification has in the past been indicated by the term interpretatio christiana. Due to the problematic nature of the term and the many ways it has been applied by past scholars (D. KinNEY, Interpretatio christiana, in B. Harvey, Jr. / C. Conybeare (eds.), Maxima debetur magistro reverentia: Essays on Rome and the Roman tradition in honor of Russell T. Scott. Biblioteca di Athenaeum, 54. Como 2009, 117-125), I prefer not to use it.

5 Reidentifications, whereby an entirely new identity was assigned, therefore differ from reinterpretations, whereby the impact and interpretation of a certain motif shifted but was not entirely changed.

6 For an overview of the development of negative Christian attitudes in Late Antiquity, see I. JACOBS, From production to destruction? Pagan statuary in late antique Asia Minor. AJA 114 (2010), 267-303; B. CASEAU, Religious intolerance and pagan statuary, in L. Lavan/M. Mulryan (eds.), The archaeology of late antique 'paganism'. Late Antique Archaeology, 7. Leiden/Boston 2011, 479-502. Rare attempts to continue the statuary habit in a Christian guise are discussed in B. WARD-PERKIns, Four bases from Stratonikeia: a (failed) attempt to Christian- 
tinue statuary have been debated on several occasions. ${ }^{7}$ Stand-alone statues supposedly invited veneration and were therefore too reminiscent of pagan idolatry. ${ }^{8}$ Michael Peppard has explained the averseness to statues of Christ by stressing that Christians would have considered them too similar to statues of the emperor, the worship of which they had so strongly protested, whilst also being aware of the vulnerability of statues, ${ }^{9}$ whereas Paolo Liverani has argued that two-dimensional portraits allowed for the development of a code-language that conveyed particular details about the honorand. ${ }^{10}$ Regardless of the exact reason why, the established list of purpose-made freestanding stone and metal statues depicting Christian subjects is short, whereas also relief decoration had clearly become far less popular than in preceding centuries. It is worthwhile briefly enumerating the known examples and categories of evidence in order to demonstrate how scarce traditional three-dimensional imagery seemingly became especially once the fourth century was over. ${ }^{11}$

In addition to general references to heretics worshipping statues of Christ, ${ }^{12}$ literary sources mention specific examples of Christian statuary as well. Thus the

ize the statue habit, in A. Busine (ed.), Religious practices and Christianization of the late antique city (4th-7th cent.). Leiden 2015, 179-187 and A. Avdokhin, Christianizing statues unawares? Imperial imagery and New Testament phrasing in a late antique honorific inscription (IEph 4.1301). ZPE 116 (2020) 1-17.

7 See, for instance, R.M. Jensen, Face to face. Portraits of the divine in early Christianity. Minneapolis 2005, 9-30; K. MARSENGILL, The Christian reception of sculpture in late antiquity and the historical reception of late antique Christian sculpture. Journal of the Bible and its Reception 1/1 (2014), $67-101$, on 69-71.

8 JACoBs, From production to destruction? (as footnote 6 above), 289.

9 M. PEPPARD, Was the presence of Christ in statues? The challenge of divine media for a Jewish Christian god, in L.M. Jefferson/R.M. Jensen (eds.), The art of empire: Christian art in its imperial context. Minneapolis 2016, 225-269, esp. 252-259.

10 P. Liverani, The sunset of 3D, in T.M. Kristensen/L. Stirling (eds.), The afterlives of Greek and Roman sculpture. Late antique responses and practices. Ann Arbor 2016, 310-329.

11 Several modern authors mention examples known from literary sources and/or surviving statuettes: H.J. HoRNIK, Freestanding sculpture, in R.M. Jensen/M.D. Ellison (eds.), The Routledge Handbook of early Christian art. London/ New York 2018, 73 - 85 focusses on the iconography of the most famous examples. MARSENGILL, Christian reception (as footnote 7 above), 77 81, 91 is the most complete overview so far. R. M. JEnSEN, Art, in P. F. Esler (ed.), The early Christian world. London/New York 2017, 717 - 744, esp. 734 offers a rather vague list of early Christian sculpture. The popularity of two-dimensional portraits, both monumental and portable, is discussed in K. MARSEngiLl, Portraits and icons. Between reality and spirituality in Byzantine art. Byzantios, 5. Turnhout 2013.

12 Irenaeus, Adversus Haereses 1.25.6 (last quarter second century AD), repeated in Epiphanius, Panarion 27.6.9 (last quarter fourth century AD). Irenaeus's text has been used in discussions on the earliest painted portraits of Christian holy persons. See MARSENGILL, Portraits and 
Historia Augusta claims that the emperor Severus Alexander included a statue of Christ in his lararium. ${ }^{13}$ Far more famous were the donations by Constantine, including the $5 \mathrm{ft}$ high silver statuary groups of Christ and the Apostles and of Christ and four angels that decorated the Fastigium of the Lateran basilica. ${ }^{14}$ Constantine also bestowed a gold lamb, silver statues of Christ and John the Baptist as well as statues of deer to the Lateran baptistery. ${ }^{15}$ According to Eusebius the emperor moreover decorated fountains in Constantinople with Good Shepherds, as well as a gold-plated brass statue of Daniel and lions. ${ }^{16}$ Material evidence consists of some thirty under-life-sized third- and fourth-century statues of shepherds that may or may not have been identified as the Good Shepherd. ${ }^{17}$ Almost all of them originated as table supports, but some were found in funerary contexts, whereas others show signs of having been reused as fountain figures. ${ }^{18}$ Other examples include the third-century Good Shepherd

icons (as footnote 11 above), 27 and EADEM, Panel paintings and early Christian icons, in Jensen/Ellison, Routledge Handbook (as footnote 11 above), 191-206, on 202. Marsengill interprets the images mentioned as panel paintings, though the addition of "formed of other materials" could indicate that three-dimensional portraits existed as well. Both Irenaeus' and Epiphanius' passages are discussed briefly in PePpard, Presence (as footnote 9 above), 240. 13 Historia Augusta, Severus Alexander 29.1 - 2. See PepPARD, Presence (as footnote 9 above), 240-241. MARSEngILl, Portraits and icons (as footnote 11 above), 27 again prefers to see these as two-dimensional depictions.

14 Liber Pontificalis 34.9-10; B. WARD-PERKINS, The end of the statue habit, AD 284-620, in R. R. R. Smith / B. Ward-Perkins (eds.), The last statues of Antiquity. Oxford 2016, 304-305, LSA508 and 509; PEPPARd, Presence (as footnote 9 above), $245-251$ and LivERANI, Sunset (as footnote 10 above), 320-321 both give further references and comments on the reception of such Christian statuary in ecclesiastical contexts.

15 Liber Pontificalis 35.13, discussed in Liverani, Sunset (as footnote 10 above), 321-322 fig. 7.

16 Vita Constantini 3.49. A. Cameron/S.G. Hall (trans.), Eusebius, Life of Constantine. Oxford/New York 1999, 298; F. A. BAuER/CH. Witschel, Statuen in der Spätantike, in F.A. Bauer/Ch. Witschel (eds.), Statuen in der Spätantike. Akten des internationalen Workshops in München am 11. und 12. Juni 2004. Spätantike, Frühes Christentums, Byzanz. Kunst im Ersten Jahrtausend. Reihe B: Studien und Perspektiven, 23. Wiesbaden 2007, 1-24, see 14.

17 Peppard, Presence (as footnote 9 above), 238, on the polyvalent nature of pre-Constantinian Christian statuary.

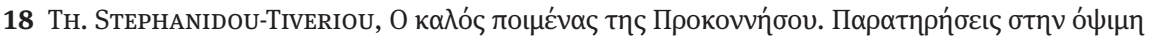

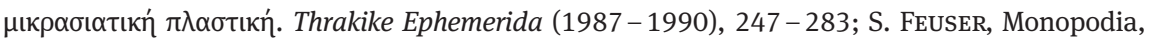
figürliche Tischfüße aus Kleinasien: ein Beitrag zum Ausstattungsluxus der römischen Kaiserzeit. Byzas, 17. Istanbul 2013, 155-161, $257-271$, cat. no. 133-162. See, for instance, M. Lidova, The rise of the image of Christ, in J. Elsner et al. (eds.), Imagining the divine. Art and the rise of world religions. Oxford 2017, 51-67, 55, fig. 33 for a Good Shepherd used as a foun-

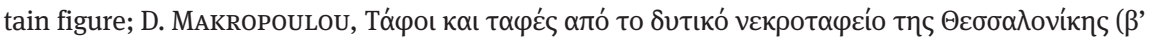

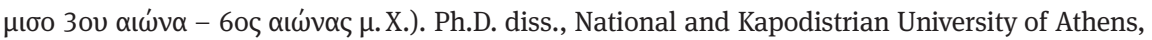


and Jonah group at the Cleveland Museum; ${ }^{19}$ and further table supports with scenes from the Jonah cycle. ${ }^{20}$ Remarkably, even examples from Constantinople are rare. They include four tondi probably depicting evangelists or apostles holding a codex, which are dated only very broadly between 300 and $500,{ }^{21}$ the marble sanctuary screens from Anicia Juliana's Church of St. Polyeuktos (built 524527) that included busts of Christ, Mary and the Apostles, ${ }^{22}$ and a late fifth- or sixth-century fragmentary torso of a man holding an open codex, also possibly an evangelist. ${ }^{23}$ A young seated figure dated to the late fourth century and produced in Asia Minor has been interpreted as Christ teaching. ${ }^{24}$ Even the production of sarcophagi or sarcophagus fragments carrying Christian relief imagery is largely confined to the late third and fourth century, with some examples dated in the first half of the fifth century. ${ }^{25}$

It has been argued that these earlier products were the result of an age of experimentation, which peaked under Constantine and came to a conclusion by the fifth century. ${ }^{26}$ Yet the Liber Pontificalis mentions some later dedications, including a 200 lb silver statue of the martyr St. Laurence, donated by pope Xys-

2007, $75-76$, pl. 74 for a shepherd discovered in funerary context. I am grateful to Panayiotis Panayides for these references.

19 E. Kitzinger, The Cleveland marbles, in: Congresso Internazionale di Archeologia Cristiana I. Vatican City 1978, 653-75; W. D. WIxoN, Portrait bust, Good Shepherd, and Jonah figures, in K. Weitzmann (ed.), Age of spirituality. Late antique and early Christian art, third to seventh century. New York 1979, 406-411.

20 FEUSER, Monopodia (as footnote 18 above), 161-165.

21 LSA-2416, 2417, 2418, 2419 with discussion and further references.

22 R.M. HARRISON (ed.), Excavations at Saraçhane in Istanbul. Princeton 1985, 156 - 157, 418;

N. Firatli, La sculpture byzantine figurée au Musée archéologique d'Istanbul. Paris 1990, nos. $485-493$, pl. $123-124$.

23 LSA-2420 with discussion and further references. The Christian identity of LSA-375 is highly debatable.

24 J. K. Kollwitz, Probleme der theodosianischen Kunst Roms. Rivista di Archeologia Cristiana 39 (1963), 191 - 233, see 222, abb. 19-20; B. BRENK, Zwei Reliefs des späten 4. Jahrhundert. Acta ad archaeologiam et artium historiam pertinentia, Institutum Romanum Norvegiae 4 (1969), 51-60, on 54, Taf. IVa; T.F. MATHEws, The clash of gods. A reinterpretation of early Christian art. Princeton 1993, 128; Jensen, Face to face (as footnote 7 above), 32; P. ZANKER, The mask of Socrates. The image of the intellectual in antiquity. Berkeley 1995, 291-292, fig. 157.

25 For recent overviews, see J. DRESKEn-WeILAND, Christian sarcophagi from Rome, in R.M. Jensen/M.D. Ellison (eds.), The Routledge Handbook of Early Christian Art. London/New York 2018, 39-55; and G. KocH, Christian sarcophagi outside Rome, ibid., 56-72, both with further bibliography.

26 Peppard, Presence (as footnote 9 above), 238-251. 
tus (432-440); ${ }^{27}$ silver figures of Christ and the twelve apostles set up by Pope Symmachus in the Basilica of St. Paul in the early sixth century; ${ }^{28}$ and finally, under the entry on pope Sergius (687-701), mention is made of three golden images of St. Peter in front of which a censer was hung. ${ }^{29}$ Material examples of loose-standing statuary postdating the fourth century are limited to the one late fifth- or sixth-century torso from Constantinople already mentioned. However, as already indicated by the Constantinopolitan examples, inside churches and baptisteries religious 'portraiture' in relief also continued. Inside ecclesiastical buildings we find not just stone, but also figurative stucco decoration up until the very end of Antiquity. Thus the Baptistery of Neon at Ravenna preserves at the level of the windows a series of prophet portraits placed in a stucco architectural frame. ${ }^{30}$ A small relief of an enthroned Theotokos with the Christ child on her lap, discovered in a church at Kalavasos on Cyprus, has been dated to the end of the sixth or the early seventh century. ${ }^{31}$ Furthermore, church decoration may also have comprised relief sculpture in wood, as suggested by the wooden doors of Santa Sabina in Rome. ${ }^{32}$

Finally, even though larger three-dimensional depictions were no longer created, it is useful to point out that at least in some locations within the Late Roman Empire, small-scale Christian statuettes continued earlier traditions. A handful of small-scale Christian statuettes in bronze survive, ${ }^{33}$ whereas at least

27 Liber Pontificalis 46.5. In comparison, the silver statue of Constantine's Fastigium was said to weigh $120 \mathrm{lb}$.

28 Liber Pontificalis 53.8. The very late date may suggest that these were rededications rather than new creations.

29 Liber Pontificalis 86.11. R. DAvis, The Book of Pontiffs (Liber Pontificalis). The ancient biographies of the first ninety Roman bishops to AD 715. Translated Texts for Historians, 6. Liverpool 2010, 110 considers them to be statues.

30 S. Kostof, The Orthodox Baptistery of Ravenna. New Haven 1965, 71-76; L. PASQUINI, Il battistero della cattedrale cattolica a Ravenna, in C. Rizzardi (ed.), Venezia e Bisanzio. Aspetti della cultura bizantina da Ravenna a Venezia (V-XIV secolo). Venice 2005, 327-344, here 338 - 344; D. DeliYannis, Ravenna in late antiquity. Cambridge 2010, 96, note 32 mentions further evidence for stucco decoration in the churches of Ravenna.

31 M. L. Rautman, A Cypriot village of late antiquity: Kalavasos-Kopetra in the Vasilikos Valley.

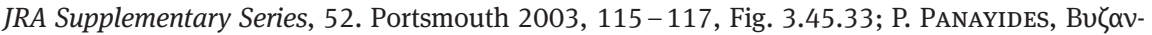

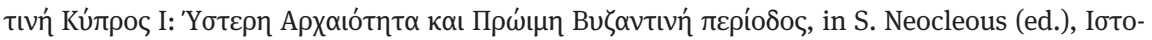

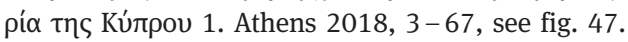

32 R. Delbrueck, Notes on the wooden doors of Santa Sabina. Art Bulletin 34 (1952), 139 145.

33 MARSENGILL, Christian reception (as footnote 7 above) 91, lists two possible statuettes of St. Peter, one possibly of St. Paul, and another possible apostle, all from the fourth or fifth century, 
two sites had a production line of ceramic statuettes continuing in the sixth century: the pottery kilns of Sagalassos in SW Turkey produced both zoomorphic and anthropomorphic small-scale figures. Surviving examples mainly consist of armed riders, some of them marked with crosses, but there is also a musician and a bishop performing an act of consecration. ${ }^{34}$ At the pilgrimage site of Abu Mina, rider figurines were manufactured, though the main product line consisted of women shown pregnant or holding children. ${ }^{35}$

In view of the apparent scarcity of material evidence, it is somewhat surprising to find the matter of Christian statuary explicitly addressed in letters by highly placed men of the church who take a unexpectedly positive stance towards the medium. Hypatius, archbishop of Ephesus between 531 and 538 as well as a close advisor to the emperor Justinian, condones the usage of Christian statues for pedagogical reasons in his response to objections against statuary veneration raised by his suffragan, the bishop of Adramyttium. ${ }^{36}$ Hypatius did not see any harm in using religious sculpture, as he considered the danger of idolatry to be a thing of the past. ${ }^{37}$ These sentiments are repeated in letters sent by Pope Gregory the Great in July 599 and October 600 to Serenus, bishop of Marseille, who destroyed images of saints present in the churches of his see. ${ }^{38}$ Although it is impossible to examine what exactly these statues depicted, how they were being used, or even how many there were, these letters again confirm that three-dimensional Christian statues still existed as late as c. 600 .

It is entirely unclear if the statues mentioned by Hypatius and Gregory were newly carved for Christian usage or if they were older items that had been repur-

as well as a seventh-century statuette of a pilgrim or saint. Two of these are discussed in HoRNIK, Freestanding sculpture (as footnote 11 above), $81-83$ as well.

34 P. TALLOEN, From pagan to Christian: religious iconography in material culture from Sagalassos, in Lavan/Mulryan, Archaeology (as footnote 6 above), 575-607, 593-596; I. JACoBS/M. WAELKENS, 'Christians do not differ from other people'. The down-to-earth religious stance of late antique Sagalassos (Pisidia), in W. Amelung (ed.), Die Christianisierung Kleinasiens in der Spätantike. Asia minor Studien, 87. Bonn 2017, 175-198, see 184-186.

35 S. BANGERT, The archaeology of pilgrimage: Abu Mina and beyond, in D. M. Gwynn/S. Bangert (eds.), Religious diversity in late antiquity. Late Antique Archaeology, 6. Leiden/Boston 2010, 291-328, on 307-308; D. Frankfurter, Female figurines in early Christian Egypt: reconstructing lost practices and meanings. Material Religion 11.2 (2015), 191-223.

36 For translation and commentary, see Efthymios Rizos, Cult of saints, E05373 - http://csla.history.ox.ac.uk/record.php?recid=E05373.

37 P.J. AleXANDER, Hypatius of Ephesus: a note on image worship in the sixth century. The Harvard Theological Review 45 (1952), 177 -184, see 181.

38 Gregory the Great, Letter 9.209 and Letter 11.10 (J.R.C. MARTYN, trans., The letters of Gregory the Great. Toronto 2004, 674 and 745 - 746). For a brief discussion, see ALEXANDER, Hypatius (as footnote 37 above), 183-184. 
posed. Both scenarios are imaginable. There certainly still was plenty of statuary around that could have served this new purpose. ${ }^{39}$ Especially in the cities of the Eastern Mediterranean, the advance of Christianity had not led to the eradication of older statues. Honorific as well as pagan-mythological statues are regularly uncovered during archaeological excavations of urban centres that were only (largely) abandoned at the end of antiquity or even later. We therefore cannot deny that, despite the many voices raised in protest against the medium, statuary remained a component of the late antique and sometimes also the Byzantine cityscape. We also must acknowledge that contemporaries chose to preserve and use at least certain images. In some cases, there is clear evidence for conscious selection. The fact that specific reasons for such selections are not explicitly mentioned in literary sources should not stop us from examining how these decisions were motivated. ${ }^{40}$

Older interpretations of surviving material evidence were often negative, ${ }^{41}$ with scholars maybe affected by Eusebius' assertion that Constantine collected statues in his capital to be derided. ${ }^{42}$ In the meantime, interest and also evidence for more positive takes on statuary in Late Antiquity has been growing, with stat-

39 WARD-PERKINS, End (as footnote 14 above), 295-307. Literature on late antique statues is too vast to cite here in full. The most vital overviews include SMITH / WARD-PERKINS, Last statues (as footnote 14 above), and T.M. KRISTENSEN/L.M. StiRLing (eds.), The afterlife of classical sculpture: late antique responses and practices. Ann Arbor 2016 for honorific and paganmythological statuary respectively.

40 C. RouechÉ, Seeing statues, in: Roman sculpture in Asia Minor. Proceedings of the international conference to celebrate the 50th anniversary of the Italian excavations at Hierapolis in Phrygia. JRA Supplementary Series, 80. Portsmouth 2011, 91-100, for similar remarks.

41 It has for instance been suggested that the seated statues on the Byzantine Esplanade in Caesarea Maritima were moved to this location and put on display without their original heads to demonstrate the impotence of the ancient (imperial) deities. See Y. TSAFRIR, The classical heritage in late antique Palestine: the fate of freestanding sculptures, in Y.Z. Eliav/E.A. Friedland/S. Herbert (eds.), The sculptural environment of the Roman Near East: reflections on culture, ideology, and power. Leuven/Dudley, MA 2008, 117 -141, see 132; T.M. KRISTENSEN, The display of statues in the late antique cities of the Eastern Mediterranean: reflections on memory, meaning, and aesthetics, in D. Sami/G. Speed (eds.), Debating urbanism within and beyond the walls A.D. 300-700. Leicester 2010, 265-291, see 280.

42 Vita Constantini 3.54. This and similar claims are discussed in H. SARAdi-MENDELovici, Christian attitudes toward pagan monuments in late antiquity and their legacy in later Byzantine centuries. DOP 44 (1990), $47-61$, see 50. It is contested in MANGo, Antique statuary (as footnote 1 above), 56 - 57; C. LEPELLEy, Le musée des statues divines. La volonté de sauvegarder le patrimoine artistique païen à l'époque théodosienne. Cahiers Archéologiques 42 (1994), 5-15, here 10; BASSETT, Urban image (as footnote 1 above), 48; JACOBS, From production to destruction? (as footnote 6 above), 290. 
ues being moved around for what have been called 'beautification reasons', ${ }^{43}$ and 'antiquarianism', ${ }^{44}$ used as political talismans and means of propaganda, ${ }^{45}$ or as signifiers of specific honourable qualities and pleasant aspects of late antique life. ${ }^{46}$ Both Christians and pagans appear to have enthusiastically participated in such reinterpretations, especially in the fourth and early fifth century. ${ }^{47}$ Over the course of the sixth century at the latest, such usages are assumed to have lessened, and contemporaries supposedly lost interest in the medium of statuary and at best passively let them be. ${ }^{48}$ An ever greater number of statues disappeared as they were reused as building material, melted down, or burned to lime for economic reasons. Nevertheless, results of recent research in cities

43 New statue bases mention as reasons for relocation ad ornatum publiciam, ad faciem publicam, or pro beatitudine temporum. See H. BRANDENBURG, Die Umsetzung von Statuen in der Spätantike, in H.-J. Drexhage/J. Sunskes (eds.), Migratio et Commutatio. Studien zur alten Geschichte und deren Nachleben (Festschrift T. Pekáry). St. Katharinen 1989, 235-246; J. CuRRAN, Moving statues in late antique Rome: problems of perspective. Art History 17 (1994), 46 - 58; LEPELLEY, Musée (as footnote 42 above); C. LEPELLEY, Recherches sur les diverses formes de paganisme dans l'Afrique romaine tardive. Les témoignages épigraphiques du IV ${ }^{\mathrm{e}}$ siècle. Compte-rendu du séminaire tenu en 1999-2000. Annuaire de l'école pratique des hautes études. Section des sciences religieuses 108 (2001), 283-287; СH. Witschel, Statuen auf spätantike Platzanlagen in Italien und Africa, in Bauer/Witschel, Statuen (as footnote 16 above), 113 169; G. KalAS, The restoration of the Roman Forum in late antiquity: transforming public space. Austin 2015, 105-108. The topos of the "beauty" of the city and the centrality of material aspects therein is discussed in H. SARADI, The kallos of the Byzantine city: the development of a rhetorical topos and historical reality. Gesta 4 (1995), 7-56.

44 BASSETT, Urban image (as footnote 1 above), 101 (Kedrenos on the statues in the Zeuxippos baths), 115-116 (the Lausos collection); C. MACHADo, Religion as antiquarianism: pagan dedications in late antique Rome, in J. Bodel/M. Kajava (eds.), Religious dedications in the GrecoRoman world. Distribution, typology, use. Rome 2009, 331-353.

45 L. LaVAn, Political talismans? Residual 'pagan' statues in late antique public space, in Lavan/Mulryan, Archaeology (as footnote 6 above), 439-477 for statues as political talismans. The bronze statues gathered in the Embolos of Ephesus were probably intended to glorify Aelia Flacilla and her importance for the Theodosian dynasty, see C. RouechÉ, The image of victory: new evidence from Ephesus, in V. Déroche et al. (eds.), Mélanges Gilbert Dagron. Travaux et Mémoires, 14. Paris 2002, $527-546$.

46 Thus Dionysiac imagery referred to the "Good Life" - see H. MAGUiRe, The Good Life, in G.W. Bowersock/P. Brown/O. Grabar (eds.), Late antiquity. A guide to the postclassical world. Cambridge, MA / London 1999, 238 -257, esp. 246 -, Apollo and the muses to a cultured life. See A. FERRARI, La rilettura cristiana dei miti pagani. Antiquité Tardive 19 (2011), 209-222 for an overview of allegorical interpretation of ancient gods.

47 T.M. Kristensen/L.M. StiRling, The lives and afterlives of Greek and Roman sculpture. From use to refuse, in Kristensen/Stirling, Afterlife (as footnote 39 above), 3-24, see 14-21. 48 Ibid., 21: "an unquantifiable amount of statuary remained passively or neutrally in place in cities and landscapes." 
such as Miletus, Aphrodisias, and Sagalassos would suggest that the role of statuary was not played out after all. Statuary relocations at these sites have been (re)dated with certainty to the sixth century, due to better and more careful excavations and reinvestigations of older research, with meticulous recording of find contexts. ${ }^{49}$ Of course, the further forward in time we push the active role of statues, the more pressing it becomes to explain why some survived until the end of antiquity and even beyond.

\section{An early start in the Constantinian period}

The earliest literary attestations of Christian refashioning of identities date to the reign of Constantine. The most informative author is Eusebius. ${ }^{50}$ In a letter to Constantia, which is best known for discussing Early Christian reception of images of the divine, ${ }^{51}$ Eusebius mentions what he esteems to be rather confounding identifications:

Once - I do not know how - a woman brought me in her hands a picture of two men in the guise of philosophers and let fall the statement that they were Paul and the Saviour - I have no means of saying where she had had this from or learned such a thing. ${ }^{52}$

Although their portable depictions are rarely preserved today, philosophers and portraits of individuals in the guise of philosophers are known to have been popular in second- and third-century funerary art. On sarcophagi, philosophers and other men of learning are usually depicted in profile, though sometimes frontally, dressed in tunic and mantle either with partially nude torso and barefoot

49 R. R. R. Smith, Statue life in the Hadrianic baths at Aphrodisias, AD 100-600. Local context and historical meaning, in Bauer/Witschel, Statuen (as footnote 16 above), 203-235; I. JACoBS / L. STIRLING, Re-using the gods. A 6th-c. statuary display at Sagalassos and a re-evaluation of pagan-mythological statuary in Early Byzantine civic space. JRA 30 (2017), 196 - 226; I. JACoBS, Pagan-mythological statuary in sixth-century Asia Minor, in I. Jacobs/H. Elton (eds.) Asia Minor in the long sixth century. Current research and future perspectives. Oxford 2019, $29-43$.

50 See also the discussion in MARSEngILl, Panel paintings and early Christian icons (as footnote 12 above), $191-192$.

51 Translated in C. MANGo, The art of the Byzantine empire 312-1453: sources and documents. Sources and Documents in the History of Art. Prentice Hall 1972, 16-18; S. GERo, The true image of Christ: Eusebius' Letter to Constantia reconsidered. The Journal of Theological Studies 32 (1981), 460-470; Jensen, Face to face (as footnote 7 above), 23 - 25 for a comprehensive discussion. The authenticity of the letter is not undisputed.

52 Eusebius, Ep. Const. (transl. MANGo, Art, as footnote 51 above, 18). 


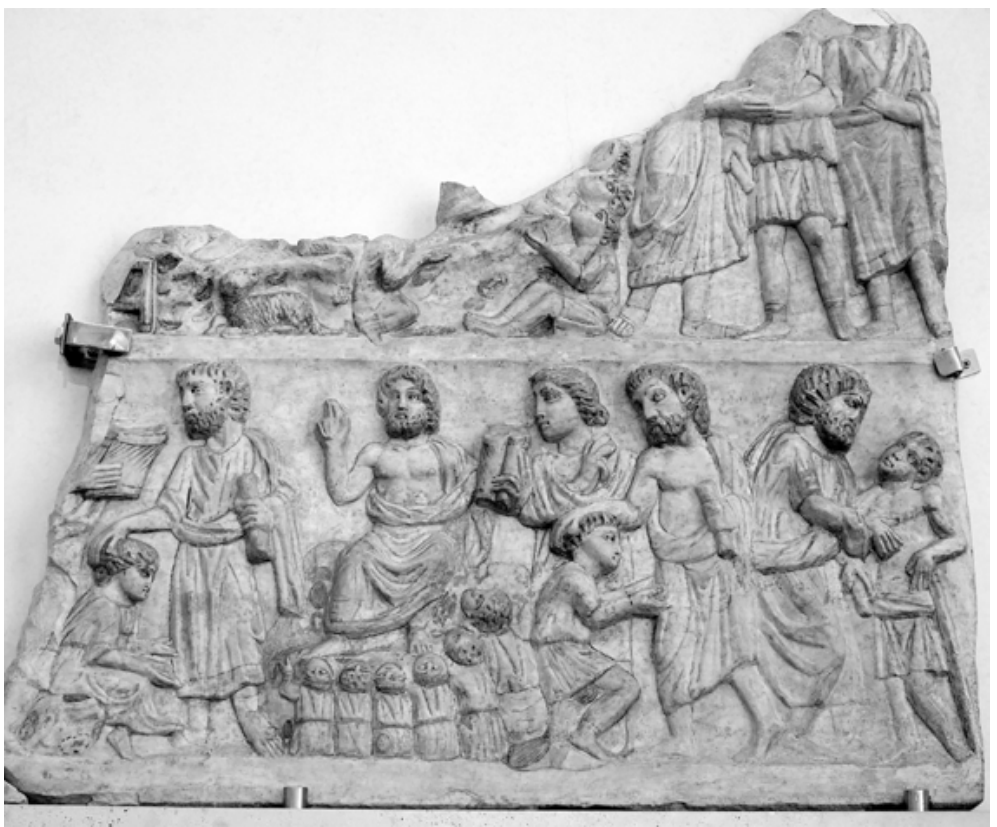

Fig. 1. Fragment of so-called "polychrome plaque" with miracles of Christ, c. AD 300, Palazzo Massimo alla Terme, Rome. Photo by G. Stafford.

or entirely covered and wearing sandals, but invariably reading from a scroll. ${ }^{53}$ The deceased as philosopher could be surrounded by other philosophers. They signified a reflective and peaceful life to non-Christians and Christian alike. ${ }^{54}$ Individuals could have their own features added to the general type, thus personalizing the message. At the same time, one particular Christian viewing of the seated philosopher identified him as Christ the Teacher. Around the year 300 a frontal-facing philosopher type appeared, still in the same garb but now holding a scroll and making a gesture of speech, which was almost certainly intended to depict Christ (Fig. 1). ${ }^{55}$

53 ZANKER, Mask (as footnote 24 above) 267-289.

54 J. Huskinson, Degrees of differentiation: role models on early Christian sarcophagi, in S. Bell / I. L. Hansen (eds.), Role models in the Roman world. Identity and assimilation. MAAR Supplementary Volumes, 7. Ann Arbor 2008, 287 - 299 on conventional and Christian interpretation of figures related to learning; M. STUDER-KARLEN, Verstorbenendarstellungen auf frühchristlichen Sarkophagen. Bibliothèque de l'Antiquité tardive, 21. Turnhout 2012, 84-107.

55 ZANKER, Mask (as footnote 24 above), 292 - 293; R. M. JENSEN, Understanding early Christian art. London/New York, 2000, 44-46; JENSEN, Face to face (as footnote 7 above), 154-159. 
Many of the earliest Christian motifs are reinterpretations and adaptations of such Graeco-Roman prototypes, with the Good Shepherd being the best-known example. ${ }^{56}$ They are probably intentionally ambiguous or polysemic. Their perceived identity depended on their association with other figures and scenes and their physical context, as well as the religious conviction of the viewer. Against the background of a still crystallizing Christian iconography and the omnipresence of polysemic imagery, ${ }^{57}$ it is hardly surprising that a Christian woman in the early fourth century saw Christ and Paul when Eusebius still saw more traditional philosopher types.

Eusebius' discomfort about depicting the divine expressed in his letter to Constantia was obviously not shared by his contemporaries, nor is it repeated in his other works. As already mentioned, Eusebius describes Christian statues dedicated by Constantine, including Good Shepherds, in his Life of Constantine. As just indicated, their more general iconography may have been given a specifically Christian interpretation by Eusebius. In his Ecclesiastical History (7.18), paintings of Peter and Paul are mentioned in a much more matter of fact manner, and Eusebius seems more prepared to accept and endorse his contemporaries' view on imagery in general, and statuary in particular. Eusebius here tells about a statue on display in Caesarea Philippi (Paneas). ${ }^{58}$ I cite the text in full, as it illuminates some of the processes involved in identifying a statue.

But since I have come to mention this city, I do not think it right to omit a story that is worthy to be recorded also for those that come after us. For they say that she who had an issue of blood, and who, as we learn from the sacred Gospels, found at the hands of our

56 For difficulties in distinguishing the Good Shepherd from a more traditional kriophoros, see STUDER-KARLEN, Verstorbenendarstellungen (as footnote 54 above), 77 - 79; FeUSER, Monopodia (as footnote 18 above), 155-161; Lidova, Rise (as footnote 18 above), 55-56. The influence of classical art on Christian iconography is discussed in K. Weitzmann, The survival of mythological representations in early Christian and Byzantine art and their impact on Christian iconography. DOP 14 (1960), 43 + 45-68; G. M. A. HANFMANN, The continuity of classical art: culture, myth and faith, in K. Weitzmann (ed.), Age of spirituality. A symposium. New York 1980, 75 -99; A. Grabar, Christian iconography. A study of its origins. Princeton 1968, 31-54. See also J. Huskinson, Some pagan mythological figures and their significance in early Christian art. Papers of the British School at Rome 42 (1974), 68-97 for associations between Orpheus, Sol and Ulysses with Christ mainly in funerary art up to the mid-fourth century.

57 For an overview, see GRABAR, Christian iconography (as footnote 56 above).

58 P.F. BEAtrice, Pilgerreise, Krankenheilung und Bilderkult. Einige Erwägungen zur Statue von Paneas, in E. Dassman/J. Engemann (eds.), Akten des 12. Internationalen Kongresses für Christliche Archäologie. Bonn, 22.-28. September 1991. Münster 1995, 524-531; and J. F. WILson, Caesarea Philippi. Banias, the lost city of Pan. London/New York 2004, 90-113 discuss all sources pertaining to this statuary group. 
Saviour relief from her affliction, came from this place, and that her house was pointed out in the city, and that marvellous memorials of the good deed, which the Saviour wrought upon her, still remained. For [they said] that there stood on a lofty stone at the gates of her house a brazen figure in relief of a woman, bending on her knee and stretching forth her hands like a suppliant, while opposite to this there was another of the same material, an upright figure of a man, clothed in comely fashion in a double cloak and stretching out his hand to the woman; at his feet on the monument itself a strange species of herb was growing, which climbed up to the border of the double cloak of brass, and acted as an antidote to all kinds of diseases. This statue, they said, bore the likeness of Jesus. And it was in existence even to our day, so that we saw it with our own eyes when we stayed in the city. And there is nothing wonderful in the fact that those heathen, who long ago had good deeds done to them by our Saviour, should have made these objects, since we saw the likenesses of His apostles also, of Paul and Peter, and indeed of Christ Himself, preserved in pictures painted in colours. And this is what we should expect, for the ancients were wont, according to their pagan habit, to honour them as saviours, without reservation, in this fashion. ${ }^{59}$

Eusebius himself does not appear entirely convinced of the identity of the statue, as suggested by the addition of the narrative voice. However, he suspects that such identifications are there to stay and thus feels it is his duty to spread the story. In that regard, it is quite interesting that he concludes his account with a reassurance that such statues of Christ had been made in the past. Creating them may not have been en vogue among Christians, it was the common thing to do for pagans. Thus, even though Eusebius may have had doubts himself, at the same time he participates in the promulgation of the Christian identification and lends it additional weight by offering an explanatory foundation story.

Philostorgius, in his own account written roughly a century later, adds that the statue was rediscovered by the Christians of Caesarea Philippi, after a period of neglect during which the identity of the statue, the reasons for its dedication and its significance had all been forgotten. ${ }^{60}$ The success of the statue's new identity is confirmed by a growing amount of pilgrims but especially by the actions of the local pagan community who, under the reign of Julian, attack the statue, tear it from its base and drag it by its feet through the streets of the city - much like pagan statues are dragged by Christians - leading to its

59 Eusebius, Ecclesiastical History 7.18 (K. LAKE, trans., Eusebius. Ecclesiastical History. Loeb Classical Library, 153. London/Cambridge, MA 1926, 175-177). See also T. WEBER, Die Statuengruppe Jesu und der Haimorrhoúsa in Caesarea-Philippi. Damaszener Mitteilungen 9 (2006), 209-216; WiLson, Caesarea Philippi (as footnote 58 above), 90-96.

60 Philostorg., HE 7.3, as epitomised by Photius, discussed in WiLson, ibid., 92. In Malalas' version of the story (Chronographia, 10.12), the woman herself, now named Veronica, is the initiator behind the statue (E. JEFFREYs/M. JEFFREYs/R. SCOTT, trans., The chronicle of John Malalas. Byzantina Australiensia, 4. Melbourne 1986, 126-127). 
destruction. ${ }^{61}$ The head was salvaged and given a place in one of the local basilicas, where it again became an object of veneration. ${ }^{62}$

This identification of an older statuary group as Christ and the Haimorrhousa has been categorized in modern scholarly literature as a misunderstanding and is considered to be misguided. ${ }^{63}$ Yet, such qualifications do not do justice to the Christians of Caesarea Philippi nor to other groups of Christian believers who saw their heroes and champions eternalized in the statues surviving in their cityscape. It would help our perception greatly if we referred to this and similar phenomena in a more neutral manner, stating that (some members of) the Christian population of Caesarea Philippi interpreted a statue in a way that was aligned with their worldview. ${ }^{64}$

By the time Eusebius reported on the Christ statue at Caesarea Philippi, the allocation of new identities was widespread, including in the new imperial capital. John Ma has recently assembled examples of statues that were given new identities in the Constantinian age once they had been brought together from all over the empire and given a new home at Constantinople. ${ }^{65}$ As part of this more general repurposing and reimagining of older statuary, some items were indeed given a Christian identity. Considering that Constantine ordered the creation of Christian statues in Rome, it is possible that the emperor also partook in the naming practice in Constantinople. He is certainly credited with assigning a Christian identity to an older statue by John Malalas in the sixth century. Malalas recounts how the emperor, when visiting the temple of an unnamed deity near Byzantium, "recognized" the monumental statue inside and "said that it represented an angel in the clothing of a monk of the Christian faith.” The pre-

61 For Christians dragging statues through the streets, see P. STEWART, Statues in Roman society. Representation and response. Oxford/New York 2003, 275-276.

62 WiLson, Caesarea Philippi (as footnote 58 above), 102-103. The topographer Theodosius, writing between 518 and 530, still mentions that statue but it remains unclear if he himself went to Paneas. See Y. Tsafrir, The maps used by Theodosius: on the pilgrim maps of the Holy Land and Jerusalem in the sixth century C.E. DOP 40 (1986), 129-145; WiLson, Caesarea Philippi (as footnote 58 above), 108.

63 For instance, P. STEWART, Continuity and tradition in late antique perceptions of portrait statuary, in Bauer/Witschel, Statuen (as footnote 16 above), $27-42$, here 33, argues that "We need not be surprised if Eusebius, or his contemporaries, have misunderstood these old statues." Liverani, Sunset (as footnote 10 above), 321, note 39 likewise uses "misunderstanding" for Byzantine allocations of Christian identities.

64 Rous, Reset (as footnote 2 above), 6-17 suggests the term "upcycling” for intentional meaningful reuse. On the importance of terminology in general, see the articles in H. BöHME et al. (eds.), Transformation. Ein Konzept zur Erforschung kulturellen Wandels. Munich 2011.

65 J.MA, Travelling statues, travelling bases? Ancient statues in Constantinople. ZPE 180 (2012), 243-249, on 246. 
cise identity of the image as the archangel Michael was apparently revealed to him in a dream. ${ }^{66}$ Likewise, the case already mentioned above, in which Eusebius accredited Constantine with using images of the Good Shepherd to decorate fountains, in all likelihood was a Christian refashioning of older ram-bearing shepherds rather than new statues specifically representing the Good Shepherd.

\section{The importance of labelling}

Establishing the 'correct' - in the sense of 'originally intended' - identity of a statue in the round or a figure depicted on a relief, in a painting, or in a mosaic is not always straightforward, not even in today's hyperliterate academic community. Without clear attributes or other iconographic clues, pagan-mythological subjects are difficult to identity. ${ }^{67}$ Distinguishing between a statue of a divinity and a real person is not always possible either, ${ }^{68}$ and honorific portraits especially pose many difficulties of exact identification. Specific characteristics usually make it possible to categorise them broadly as an imperial ruler, dignitary, learned individual, and so on, ${ }^{69}$ whereas, based on comparisons with other statues, paintings or coin portraits, we can sometimes find out their name. But even today, with all the resources and comparative material at our disposal, we often fail to do so.

Problems of identification were infinitely larger in the past and could only be avoided by adding name labels. ${ }^{70}$ Aristotle said of ancient art "one could not recognize what each thing was unless someone had inscribed it." ${ }^{" 11}$ Similarly, Pau-

66 Malalas, Chronographia, 4.9 (JefFreys/JEFFreys/ScotT, The chronicle of John Malalas, as footnote 60 above, 37). Mango has suggested the unnamed deity originally may have represented Attis, wearing a Phrygian cap that in its updated version became a form of monastic garb. C. MAngo, St. Michael and Attis. DchAE 12 (1984), 39-62, see 58-61. See also J. BeAUCAMP, Saint-Michel de Sôsthénion ou les Argonautes et l'archange, in B. Caseau et al. (eds.), Pèlerinages et lieux saints dans l'Antiquité et le Moyen Âge. Paris 2006, $13-23$.

67 See for instance M. MARvin, Freestanding sculptures from the baths of Caracalla. AJA 87 (1983), $347-384$.

68 For example, a veiled, slightly under life-sized statue from the Maison du Cinq Statues at Delos has been identified both as a statue of Tyche and a portrait statue (S. DiLLON, The Female portrait statue in the Greek world. Cambridge 2010, 113).

69 J. LenAGHAN, Cultural heroes, in Smith/Ward-Perkins, Last statues (as footnote 14 above), $259-266$, see $259-260$.

70 Lenaghan, Cultural heroes (as footnote 69 above), 264-265 for examples. M. SQUiRE, Image and text in Graeco-Roman antiquity. Cambridge/New York 2009, 150-151.

71 Aristotle, Rhetoric 140a, 21-22, discussed and translated in SQUIRE, Image (as footnote 70 above), 151. 
sanias (10.25) tells us that he was unable to identify some of the characters in an enormous painting that he saw in Delphi, because not all of them were labelled. Even though labels became much more frequent in Late Antiquity, especially for biblical figures as well as saints, many non-Christian and non-Jewish figures in narrative scenes in paintings, mosaics and reliefs still remained unnamed. ${ }^{72}$ And even though statuary in the round usually was identified in the inscription on its base, at least when displayed in public space, already from the Late Republican period onward, honorific statues were repurposed and reidentified by recutting or replacing the inscription. ${ }^{73}$ As statues were increasingly moved around and used for entirely new purposes in Late Antiquity, examples separated from their original identifiers only became more numerous. In Italy and North Africa, statues were re-erected on new bases featuring new inscriptions, which almost never mention the exact subject of the statue. ${ }^{74}$ The far-away locations of origin of the statues re-erected in Constantinople meant that they as well were detached from their heavy bases and placed on top of new ones at their final destination. ${ }^{75}$ They would have had to be reidentified, and this new identity had to be eternalized, again, in writing. As such, at least some of the statues in the baths of Zeuxippos apparently were positioned on top of bases with rather careless inscriptions simply clarifying who they were or at least who they were thought or propagated to be. ${ }^{76}$ Labels could thus have been added at any point in time and do not necessarily signpost a 'correct' identity. They only indicate that

72 R. LEAder-Newby, Personifications and paideia in late antique mosaics from the Greek East, in E. Stafford/J. Herrin (eds.), Personifications in the Greek world: from antiquity to Byzantium. Aldershot 2007, 231 - 246; R. LEADER-NEWBY, Inscribed mosaics in the late Roman Empire: perspectives from east and west, in Z. Newby/R. Leader-Newby (eds.), Art and Inscriptions in the Ancient World. Cambridge 2007, 179-199 gives an overview of the different conventions per region; S.V. LEATHERBURY, Inscribed within the image: the visual character of early Christian mosaic inscriptions. Ph.D. diss., University of Oxford 2012, 167. Conversely, Christian figures were often accompanied by labels. See Leatherbury, ibid., 168-172; MARSEngill, Portraits and icons (as footnote 11 above), passim.

73 B. Longfellow, The reuse and redisplay of honorific statues in Pompeii, in Ng/SwetnamBurland, Reuse (as footnote 2 above), 24-50, on 27-28. See also Rous (as footnote 2 above), $149-157$.

74 See footnote 43 above.

75 MA, Travelling statues (as footnote 65 above).

76 Three statue bases were recovered from these baths, one identifying 'Aischines', one referring to 'Hekabe', whereas a third was uninscribed. See S. Guberti BASSETt, Historiae custos: Sculpture and Tradition in the Baths of Zeuxippos. AJA 100 (1996) 497-498. MA, Travelling statues (as footnote 65 above) 247 considered these explanatory labels to be "of an almost "museographical' type". 
the owners or caretakers of a statue viewed it in a certain way at a specific moment in time and wished to convey this vision to others as well.

The most intriguing attestation of labelling in the context of this article is a poem written by the empress Eudocia after a visit to the healing baths of Hammat Gader (Gadara) either in 438-439 or between 443 and 445. The text was integrated in front of a passage connecting two major halls of the bath house as an epigraphic panel, probably in $455 .{ }^{77}$ The second part of the poem takes the form of an ekphrasis referring to separate areas of the bath: "Indian and Matrona, Repentinus, Elijah the Holy, Antoninus the Good, dewy Galatea and Hygeia herself, the large lukewarm pool and the small lukewarm pool, the Pearl, the old clibanus, Indian, and also another Matrona, Briara the Nun, and the [spring of the] Patriarch."78 Some of the areas are therefore identified by specific pools or water features (the large lukewarm pool and the small lukewarm pool, the Pearl, the old clibanus, the [spring of the] Patriarch ${ }^{79}$ ), others by statues. Some of these characters we would expect in a Roman bath complex, including statues of female benefactors (the two matronae, possibly also the Indians, if they represented honorands in exotic garb, Repentinus probably was a local donor), imperial statues, and personifications of water creatures (Galatea the sea nymph). ${ }^{80}$ Conversely, Elijah the Holy and Briara the Nun are quite untypical for a Roman bath house. ${ }^{81}$ In these cases, Eudocia's ekphrasis no doubt reflects contemporary

77 L. Di SEgnI, The Greek inscriptions of Hammat Gader, in Y. Hirschfeld (ed.), The Roman baths of Hammat Gader. Final Report. Jerusalem 1997, 185-266, here 228-233, no. 49. The text was found in Area D, opposite the passage leading to Area A. For an extensive discussion on the text, see S. Busch, Versus Balnearum. Die antike Dichtung über Bäder und Baden im römischen Reich. Stuttgart/Leipzig 1999, 84-97.

78 Di SEgNi, Greek inscriptions (as footnote 77 above), 229; Busch, Versus Balnearum (as footnote 77 above), 86, with adjustment to "Briara the Nun" suggested by Ida Toth. J. GREEN / Y. TsAFRIR, Greek inscriptions from Hammat Gader: a poem by the empress Eudocia and two building inscriptions. Israel Exploration Journal 32 (1982), 77 -96, on 80 as well as DI SEGNI, ibid., 229 opt for the translation "Briara and the nun", although the first also suggest considering $\mu$ ovó $\sigma$ $\tau \rho ı \alpha$ as an adjective, "the mighty nun". Busch, ibid., 93, opted for "Briara, nun."

79 GrEEN/TsAFriR, Greek inscriptions (as footnote 78 above), 90-91; E. R. HABAS, A poem by the empress Eudocia: a note on the patriarch. Israel Exploration Journal 46 (1996), 108-119 argues for a contemporary Judaic patriarch; Busch, Versus Balnearum (as footnote 78 above), 93, leaves the question open.

80 GREEN/Tsafrir, Greek inscriptions (as footnote 78 above), $87-88$.

81 Overviews of statue subjects present in baths can be found in H. MANDERSCHEID, Die Skulpturenausstattung der kaiserzeitlichen Thermenanlagen. Berlin 1981; MARviN, Freestanding sculptures (as footnote 67 above); R. BoL, Marmorskulpturen der römischen Kaiserzeit aus Milet. Aufstellungskontext und programmatische Aussage. Funde aus Milet 2. Milet, 5.2. Berlin, 2011; JACOBS, From production to destruction? (as footnote 10 above) Appendix; L. M. STIRLING, 
identification. ${ }^{82}$ The Elijah most likely represented the prophet Elijah, who in late antique literary sources is named as a role model for monastic life and depictions of whom are known from wall paintings and sarcophagi as well as from the wooden doors of Santa Sabina mentioned above. ${ }^{83}$ Who Briara the Nun was and why she mattered to contemporaries remains entirely unknown.

In this ekphrasis, Eudocia may have incorporated information conveyed to her orally, but, as the bases from the Baths of Zeuxippos indicate, she may also have repeated what was written on the bases of the statues. A confirmation of the existence of such Christian epigraphic labels comes from Echinos in Thessaly. Excavations of a small church outside the walls of the city uncovered a cubic stone base of a bronze statue, bearing an inscription that identified the honorand as Saint Athanasios of Alexandria. The production of a bronze statue of an Alexandrian bishop for such a modest building - the church is not even 10 meters long - in a small town in Thessaly seems highly unlikely. ${ }^{84}$ It is far more plausible that an older item deemed well-suited for the representation of a high ecclesiastical official had been taken from elsewhere. Adding a new inscription was enough both to fashion and to stabilize a new identity for the statue.

In contrast to the baths of Gadara, where Elijah and Briara the Nun were possibly already on display before their identity change, the example at Echinos was very much an intentional act. The people responsible for the new identity recovered the statue from elsewhere, had it transported to this small church and added the inscription to the base. Presumably this process mirrored that at Caesarea Philippi described above. Philostorgius mentions an inscription clarifying the proper identification of the statues there as well. Wilson argued that the original text on the base may have contained general titles that could easily be reinterpreted in a Christian sense. ${ }^{85}$ However, since Eusebius makes no mention of

Patrons, viewers, and statues in late antique baths, in S. Birk/B. Poulsen (eds.), Patrons and viewers in late antiquity. Aarhus Studies in Mediterranean Antiquity, 10. Aarhus 2012, $67-81$. 82 The phrasing used in RouechÉ, Seeing statues (as footnote 40 above), 93, that the "subjects do not all sound 'modern", is quite unlucky, as this was the fifth-century, modern interpretation of them.

83 R. KRAWIEC, "Garments of Salvation": representations of monastic clothing in late antiquity. JECS 17 (2009) 125-150; P. LANdesmann, Die Himmelfahrt des Elija. Entstehen und Weiterleben einer Legende sowie ihre Darstellung in der frühchristlichen Kunst. Vienna/Cologne/Weimar 2014, for an overview of early depictions.

84 O. KARAGIORGOU, Urbanism and economy in late antique Thessaly ( $3^{\text {rd }}-7$ th century AD). The archaeological evidence. Ph.D. diss., University of Oxford 2003, 88-89.

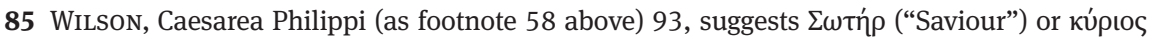

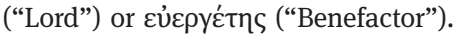


the inscription at all, it is more likely that a label was applied in the century in between the two accounts, to make the new identity permanent.

\section{Incentives for and instigators of Christian identifications}

Although it can thus be established that imaginative manipulations of identity were taking place and were on occasion also 'eternalized' in the form of inscriptions, we rarely find information on how intentional such reidentifications were or who was responsible. Eusebius remains very vague on the latter point, using the narrative voice presumably to indicate the local population of Caesarea Philippi. In his letter to Constantia, he is explicit about his own ignorance concerning the origin of the Christian identification. Eudocia may have been expressing her personal vision, but it is more likely that she wrote down what she was told and/or read on the bases when visiting the baths. In line with what is known of informants in past centuries, ${ }^{86}$ local Christian populations were no doubt responsible both for the conveyance and also the conception of new identities. I would moreover like to point to the involvement of local bishops in these processes. $^{87}$

We get an idea of the role of bishops in conveying information to travellers and no doubt also to their community from the travel account of Egeria. When Egeria visits Edessa, it is the bishop who shows her "huge" marble portraits of King Abgar and his son. ${ }^{88}$ When she is travelling through the desolate city of Rameses, she comes face to face with "Theban stone" (porphyry) statues presented to her as Moses and Aaron by the bishop of the nearby city of Arabia. ${ }^{89}$ It is safe to assume that certainly the latter were not originally carved to depict two Old Testament prophets. Yet information provided by the bishop can be considered trustworthy because he was, as Egeria adds, "a man of some age, of a

86 C.P. JonEs, Pausanias and his guides, in: S.E. Alcock/J.F. Cherry/J. Elsner (eds.), Pausanias: travel and memory in Roman Greece. New York 2001, 33-39.

87 Similarly, it has been suggested that bishop Epiphanius may have been the driving force behind the chiselling away of genitals of naked statues on display in the baths of Salamis. See P. PANAYIDES, Castrating the gods of Salamis, Cyprus: a case study on the sexual mutilation of statuary in late antiquity, in C. Ioannou / T. Mavrojannis / S. Rogge (eds.), Salamis of Cyprus. History and archaeology from the earliest times to late antiquity. Schriften des Instituts für Interdisziplinäre Zypern-Studien, 13. Münster/New York 2019, 706-718.

88 Egeria, 19.6. J. WiLKINSON (trans.), Egeria’s travels. London 1971, 115.

89 Egeria, 8.1-3; WiLKINSON, ibid., 102. 
godly life since the time he became a monk, and an approachable man, who is very good at welcoming pilgrims and also very knowledgeable about God's Scriptures". ${ }^{90}$

This stressing of trustworthiness founded on superior knowledge is a recurrent theme; when Eusebius mentions the Good Shepherds at the fountains of Constantinople, he adds that they were "evident signs to those who start from the divine oracles."91 Egeria's experience in Rameses moreover is very much reminiscent of the late antique ekphrastic tradition, with the bishop taking the place of the late antique poet. A brief comparison between, for instance, Christodorus of Coptus' ekphrasis on the baths of Zeuxippos and the explanation received by Egeria - and many Christians like her, both at Rameses and elsewhere - shows they are two sides of the same coin. ${ }^{92}$ In both cases, an unknowing audience is present: the viewers of the baths in the first and travelling Christians in the second. Though they themselves are not capable of interpreting what they see, they can rely on external sources of information: Christodorus and the bishop of Arabia respectively. Both informants have the credentials to prove that their explanation is the correct one: Christodorus has a reputation as a poet in the Homeric tradition and can thus identify characters from the story of Troy, whereas the bishop is very knowledgeable of the Bible. Both are therefore qualified to guide viewers towards the correct identification: ${ }^{93}$ specific characters from the Iliad or Aeneid with Christodorus, specific biblical figures with the bishop of Arabia.

Mary Whitby's estimate of Christodorus' achievement goes as follows: "Faced with a collection of statues that included a number of beardless naked youths, figures wreathed in laurel, and draped women, Christodorus gives them life and meaning by relating them to the familiar material of myth, often the Trojan story [...]." ${ }^{94}$ It is not hard to imagine a Christian variant of this, where-

90 Egeria, 8.4-5. Wilkinson, ibid., 102.

91 Vita Constantini 3.49 (transl. CAMERon/HaLl, as footnote 16 above, 140).

92 On Christodorus' ekphrasis of the baths of Zeuxippos, see A. KALDELLIS, Christodorus on the statues of the Zeuxippos baths: a new reading of the Ekphrasis. GRBS 47 (2007), 361-383; M. WhitBy, Christodorus of Coptus on the statues in the Baths of Zeuxippus at Constantinople: text and context, in H. Bannert/ N. Kroell (eds.), Nonnus of Panopolis in context II: poetry, religion, and society. Proceedings of the international conference on Nonnus of Panopolis, $26^{\text {th }}-29^{\text {th }}$ September 2013, University of Vienna, Austria. Leiden/Boston 2016, 271-288.

93 R. WeBB, Ekphrasis, imagination and persuasion in ancient rhetorical theory and practice. Farnham/Burlington 2009.

94 WhitBy, Christodorus (as footnote 92 above), 282. 
by a Christian bishop, faced with a number of unidentified statues untethered from their intended identity, gave them new life and meaning by relating them to the familiar stories of the Christian past, often the Bible. Although other mechanisms behind the allocation of new identities can and should not be excluded, it seems very plausible that local imaginative bishops were involved in the Christian rebranding of old images. In some cases, reidentification may have taken place in order to explain the presence of noteworthy statues in the landscape. Their new identity could even be accompanied by a complete foundation story referring to events from the Bible or to the deeds of remarkable Christians from the age of persecution. Thus Malalas tells the lengthy tale of five bronze female statues "standing at that public bath [of Antioch] to the present," who supposedly depicted five pious Christian woman martyred by the emperor Trajan.95 Yet it is also possible that older statues were deliberately sought out to depict local Christian celebrities. Parallel to what had happened in the pre-Christian past, such celebrities as well as tangible traces of a locality's importance in Christian history were potential sources of patriotic pride. ${ }^{96}$ These statues certainly did not do their communities any harm. In the case of Caesarea Philippi for instance, the statue of Christ ensured a stream of pilgrims who kept on coming even after the destruction of the group under the reign of Julian.

\section{Formal prompts for reidentification}

We can ask ourselves what or whom the statues eventually reimagined as various Christian figures originally were meant to depict. Analysing the original identity of reidentified statues is not the purpose of this article though, and, as already suggested, the generous attention given to the originally intended viewing of statuary has often led to the neglecting of later identities. My reason for turning to this aspect here is to point out that alternative identities were instigated by specific visual cues - postures, attributes, and dress styles - that were more meaningful to late antique and later viewers than they are to academ-

95 Malalas, Chronographia 11.10 (JefFreys/JEFFreys/Scott, Chronicle, as footnote 66 above, 146).

96 Pausanius (3.22.4) for instance promotes a relief of what probably originally was a bearded mountain god carved in the thirteenth century BC near his native Magnesia as the oldest depiction of Cybele, see F. Rojas / V. SergueEnkova, Traces of Tarhuntas: Greek, Roman, and Byzantine interaction with Hittite monuments. Journal of Mediterranean Archaeology 27 (2014) 135 160 , on 154. Rous, Reset (as footnote 2 above) researches the relation between purposeful reuse and community building in Athens throughout the centuries. 
ic researchers. Dale Kinney could confirm this for the rider statue of Marcus Aurelius in Rome, an exceptional case where the statue can be examined together with multiple sources pertaining to later, ever-developing viewings from the tenth century onwards. ${ }^{97}$ By contrast, as none of the statues featuring in Byzantine literary sources have been preserved, and vice versa, testimonies pertaining to the material examples I will discuss later on in this article do not exist, all suggestions made here must remain hypothetical.

A good place to start is the statue group at Caesarea Philippi. Modern researchers, after analysis of Eusebius' testimony and other, related passages from later historians, have suggested that the figures on display were originally intended to depict the emperor Hadrian accepting homage from the province of Judaea personified as a kneeling female or, more likely, Asclepius or another healing deity, with one hand lifted up in the air and a suppliant in front of him. ${ }^{98}$ Christians would have had little difficulty seeing Christ in the bearded protagonist, as there were many similarities between the iconography of Asclepius and some late third-century depictions of Christ, including the bare chest and full beard (Fig. 1). ${ }^{99}$ In this case, the bearded protagonist, the suppliant woman, and the granting of a wish expressed in an outstretched hand were ample cause for reidentification.

The abovementioned gold-plated brass statue of Daniel and the lions that, according to Eusebius, was dedicated by Constantine at Constantinople may have been a reidentification as well. ${ }^{100}$ There are not many Roman male statues with accompanying lions - a statue of Hercules fighting the Nemean lion would not have been appropriate for this particular reinterpretation - but perhaps a new combination was made between a male statue and freestanding lions, of which there were plenty from Roman and pre-Roman times. Also at Constantinople, a bronze statue of a bishop holding a staff originally must have been an image of Asclepius, considering Byzantine sources mention that the staff was

97 KInNEY, Horse (as footnote 3 above), especially 385. B. ANDERSon, Constantinople's medieval antiquarians of the future, in: Cities as palimpsests? Urban evolutions in the Eastern Mediterranean. Cambridge (forthcoming), makes a very similar argument about the interpretation of statuary by the authors of the Patria being driven by close and "direct observation."

98 See Weber, Statuengruppe (as footnote 59 above), 212; Wilson, Caesarea Philippi (as footnote 58 above), 90-94. BeAtrice, Pilgerreise (as footnote 58 above), 525, contests that the group depicted Hadrian. AvdokHIN, Christianizing (as footnote 6 above) provides a useful overview of the iconography.

99 Mathews, Clash of Gods (as footnote 24 above) 69-72.

100 This was already suggested by CAMERon/HaLl, Eusebius (as footnote 16 above), 298. 


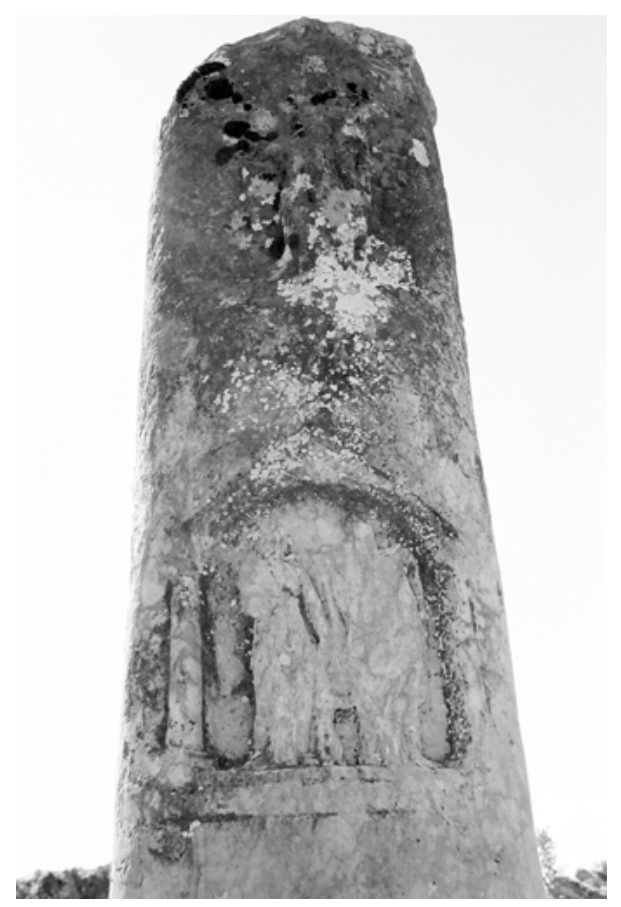

Fig. 2. Victory reliefs in the atrium of the Triconch House at Aphrodisias. Photo by the author.

snake-entwined. ${ }^{101}$ A group of one man and three women standing on columns in the hippodrome was identified in the Parastaseis as Adam and Eve with the

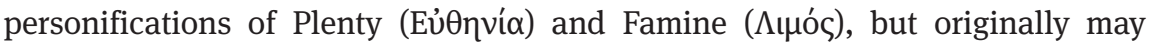
have depicted Herakles and the Hesperides sisters. ${ }^{102}$ The prompt for the alternative viewing in this case must have been provided by the tree, apple, and serpent with which Herakles was commonly depicted. ${ }^{103}$

In the archaeological record, a good candidate for such reidentification through 'recognition' of a certain prompt can be found at Aphrodisias. One of

101 MANGo, Antique statuary (as footnote 1 above), 63; BASSETT, Urban image (as footnote 1 above), 148, cat. no. 16, citing Leo Grammaticus, 257 and Symeon Magistros, 692 = Symeonis magistri et logothetae chronicon, c. 132.14, ed. S. WAHLGREN. CFHB, 44/1. Berlin 2006.

102 Parastaseis $\S 5=$ Patria 2.87. MAngo, Antique statuary (as footnote 1 above), 63; G. DAGRoN, Constantinople imaginaire. Études sur le recueil des Patria. Bibliothèque byzantine. Études, 8. Paris 1984, 135. S. Guberti Bassett, The antiquities in the Hippodrome of Constantinople. DOP 45 (1991), 87 - 96, see 91; BASSETT, Urban image (as footnote 1 above), 11, cat. no. 134. 103 Guberti BAssett, Antiquities (as footnote 102 above), 91. 
the double half-columns in the peristyle courtyard of the Triconch House at Aphrodisias features reliefs of winged females set in small panels (Fig. 2). ${ }^{104}$ The top panel, with one winged figure, is badly preserved. The lower shows two winged females in long garments standing underneath an arch. The reliefs, which predate the late antique house, were reused also in the Mid-Byzantine phases, from the late eighth or early ninth century until the twelfth century, when it functioned as the residence of the bishop of Aphrodisias. ${ }^{105}$ In this phase at the latest, the figures could easily have been read as depictions of angels. ${ }^{106}$ The winged angel, with flowing robes and asexual appearance, had indeed become a widespread motif from the late fourth century onwards. ${ }^{107}$ The fast-growing popularity of angels is obvious in their importance in scenes such as the Annunciation, the Nativity, and Resurrection but even more so in their appearance as stand-alone guardians, messengers, and psychopomps in paintings and mosaics, on sarcophagi, ceramic lamps, and so on. Given that such winged angels were derived from and thus very close in appearance to depictions of winged genii and Victoria/Nike, ${ }^{108}$ it is no surprise that they would have been 'recognized' in older material culture as well.

104 M. L. Berenfeld, The triconch house. Aphrodisias, 11. Wiesbaden 2019, 41-44, 72 describes the reliefs in detail and proposes an original identification of the lower figures as Nemeseis and of the upper one as either another Nemesis or Victoria/Nike. M. L. BERENFELD, The triconch house and the predecessors of the bishop's palace at Aphrodisias. AJA 113 (2009) 203229, 218 still identifies the three figures as Victoria/Nike.

105 BERENFELD, Triconch house (as footnote 104 above), 224-226.

106 H. JEFFERY, Eight hundred years of the cult of the Archangels at Aphrodisias/Stauropolis: modern and ancient narratives, in M. Kinloch / A. MacFarlane (eds.), Trends and turning points. The Medieval Mediterranean, 117. Leiden 2019, 205-228, suggests that, considering the popularity of the archangels Michael and Gabriel, the reliefs were reinterpreted in this specific manner.

107 Before that period, angels were commonly depicted as wingless, human-like beings. After 400 as well, wingless angels appear, as the presence of wings depended on the nature of their activity and the context in which angels were depicted, see G. PEERs, Subtle bodies. Representing angels in Byzantium. The Transformation of the Classical Heritage, 32. Berkeley/Los Angeles/ London 2001, 36 - 41. For the late antique iconography of angels, see G. STUHLFAUTH, Die Engel in der altchristlichen Kunst. Freiburg 1897; TH. Klauser, s.v. Engel X (in der Kunst). RAC 5 (1962), 5258 -5322; PeERs, ibid., 23 - 25; C. Proverbio, La figura dell'angelo nella civiltà paleocristiana. Pian di Porto 2007, 41-95. E. JASTRZĘBowSKA, New Testament angels in early Christian art: origin and sources. Swiatowit. Annual of the Institute of Archaeology of the University of Warsaw 8 (2009-2011), 153-164 focusses on the fourth to sixth-century iconographic development of New Testament angels.

108 PEERS, Subtle bodies (as footnote 107 above), 25-27 for a summary of resemblances and differences in gender and dress, with further bibliography; 27-36 discusses further iconographic proto-types. 
In other cases, prompts may have been less specific. The identification of statues in Rameses as Moses and Aaron may simply have been based on the fact that the Hebrew Bible states that Aaron lived in this eastern border-land of Egypt. Likewise, a certain pose or dress may have been enough reason for reidentification. Thus, the posture of a seated statue at Constantinople, the chin propped on a hand, was enough for Byzantines to perceive the wisdom represented in the statue and to identify it with Solomon. Originally, it must have depicted a philosopher, poet, or some other man of letters. ${ }^{109}$ For the statue identified as the bishop Athanasios in Echinos, we may surmise a seated philosopher as well. The statue identified as Briara the Nun in Eudocia's poem may have been an older honorific portrait statue, the veil of which covered the hair, if not the lower part of the face as well. ${ }^{110}$ Such a hypothesis is based on the assumption that nuns already in the fifth century distinguished themselves from lay women and that the statue reidentified as such must have had at least some resemblance to a contemporary nun. As far as we can tell, like lay women, nuns wore a tunic and cloak. ${ }^{111}$ In addition, they invariably covered their head with a veil or maphorion. ${ }^{112}$

Yet, once observation had established a prompt, it made contemporary viewers overlook other features that, at least to us, contradict the new identification. Returning to the Christ statue in Caesarea Philippi, the prompts that caused the association with the story of the Haimorrhousa are fairly easy to identify: Early Christian renderings of the scene in the catacombs, on sarcophagi, textiles, and so on depict the woman, often on her knees, sometimes with her left hand stretching out in supplication. ${ }^{113}$ In front of her stands Christ, who is turned to-

109 Leo Grammaticus 257-258 and Patria 2.40, discussed in MANGo, Antique statuary (as footnote 1 above), 62-63; BASSETT, Urban image (as footnote 1 above), 155-156 cat. no. 23. 110 The veil originally indicated the woman was of marriageable age or married (DiLLON, Female portrait statue, as footnote 68 above, 82, 110, 121, 133). L. LLEWELLYN-JonES, Aphrodite's tortoise. The veiled woman of Ancient Greece. Swansea 2003, discusses the practice of veiling in the Greek world. For use of the veil with late antique statues, see K. ScHADE, Frauen in der Spätantike - Status und Repräsentation. Eine Untersuchung zur römischen und frühbyzantinischen Bildniskunst. Mainz 2003, 116.

111 J. BALL, Decoding the habit of the Byzantine nun. Journal of Modern Hellenism 27-28 (2009-2010), 25 - 52 discusses literary and iconographic evidence for Byzantine nuns; KRAwIEC, "Garments" (as footnote 83 above).

112 BALL, Decoding (as footnote 111 above), 32.

113 P.C. Finney, Do you think god is a magician? (Plato, Rep. 380D), in K. Kirchhainer/G. Koch (eds.), Akten des Symposiums "Frühchristliche Sarkophage": Marburg, 30.6.-4.7.1999. Mainz 2002, 99-108, see 101, Healing types 3 (woman standing) and 4 (women on her knees). 
wards her and points in her direction, indicating healing. ${ }^{114}$ However, at the same time, it is clear that some aspects of the statuary group at Caesarea Philippi did not match the details of the biblical story or other early depictions. There is no biblical explanation for the plant growing at the statue's feet nor does it appear in other renderings of the scene. Elsewhere, the woman is always depicted touching the hem of Christ's robe with her right hand, obviously the key element of the miracle but apparently absent in the iconography of the Caesarea Philippi statue.

Cues for reidentification are of course not limited to Christian examples. Laurel wreaths were enough to make Christodorus see Homeric prophets in the Zeuxippos baths. ${ }^{115}$ Interestingly, the Parastaseis (§43) describes a statue that presumably stood at the Milion as a "porphyry statue [...] of three stones with three stone heads, which some said was Constantine the Great in the middle, Constantius on the left, and Constans on the right with two feet but six hands - a strange spectacle for those who saw it, each one looking in a different direction - and one head." 116 The three upper bodies indicate that the statue originally embodied the goddess Hekate, of whom statues with one head but three profiles looking in diverse directions survive. ${ }^{117}$ The most obvious cue for the imperial reidentification is the material that the statue was made from, porphyry. ${ }^{118}$ In addition, the connectedness of the three porphyry torsos would have been reminiscent of the porphyry groups of embracing tetrarchs. They themselves had been reidentified as Constantine's sons and gave their name to the square where they were reerected, the Philadelphion. ${ }^{119}$ With this in mind, the reidentification of the por-

114 Even though according to the original story the woman with the issue of blood secretively approaches Christ from behind to touch the hem of his robe, Early Christian healing miracle iconography has Christ turned towards the recipient of the miracle (JENSEN, Understanding, as footnote 55 above, 120-123).

115 WhitBy, Christodorus (as footnote 92 above), 281.

116 Transl. Cameron/Herrin, Eusebius (as footnote 1 above), 117-119.

117 The statue is discussed in BASSETt, Urban image (as footnote 1 above), 11, cat. no. 159. 118 The usage of porphyry for imperial statues has been discussed in multiple publications, including L. NiSTA, Sculpture in porphyry. The togatus from the Roman Forum, in M. Anderson/L. Nista (eds.), Radiance in stone: sculptures in colored marble from Museo Nazionale Romano. Rome 1989, 35-45; P. Malgouyres / C. Blanc-Riehl, Porphyre: la pierre pourpre des Ptolémées aux Bonaparte. Paris 2003, 35-41; D. Del Bufalo, Porphyry. Red imperial porphyry. Power and religion (trans. D. Graham/L. Cox). Turin/London 2012, 24-34. 119 F. A. BAUER, Stadt, Platz and Denkmal in der Spätantike. Untersuchungen zur Ausstattung der öffentlichen Raums in den spätantiken Städten Rom, Konstantinopel und Ephesos. Mainz 1996, 232-233; LSA-4 and LSA-439, discussion by M. BERGMANN. The date of the transfer and the cutting up of the original porphyry column to which the tetrachs belonged is discussed in P. NiewöhneR/U. Peschlow, Neues zu den Tetrarchenfiguren in Venedig und ihrer Aufstel- 
phyry Hekate as a second monument to Constantine's sons and successors Constantius and Constans is less surprising, even though the female heads and the joined bodies to the modern mind are far from apt for imperial portraits.

Some of the Byzantine viewings of an equestrian statue on the Forum Tauri at Constantinople likewise are extreme cases of reidentification to modern eyes. ${ }^{120}$ The imperial statue, a colossal bronze rider statue, is described by Niketas Choniates as a rider with a globe in his left hand. He had his right hand outstretched, as is common for depictions of Roman rulers as sign of adlocutio, adventus, or similar. Under the uplifted foot of the horse, a small figure of a barbarian was present, confirming that this was an imperial rider statue. ${ }^{121}$ Though several Byzantine sources identified the statue as one of Theodosius, some inhabitants of Constantinople apparently saw it as Bellerophon whereas others claimed that is was Joshua, two rather divergent and not obvious alternative interpretations. ${ }^{122}$ The identification of Bellerophon may have been based on the motif of a rider conquering an opponent, even though, at the same time, contemporaries must have recognized that the opponent depicted in this statue group bore no resemblance to the Chimaera and that the horse was wingless. Choniates recounts how the identification as Joshua was based on the outstretched hand of the rider, a gesture related to the events at the Battle of Gabaon (Gibeon) as can be read in the book of Joshua 10:12-13. In Early Christian and Byzantine depictions of the scene, Joshua is shown, hand outstretched, but on foot, not on horseback. ${ }^{123}$ There were therefore plenty of visual aspects that were highly contradictory to Joshua as well as to Bellerophon. In particular,

lung in Konstantinopel. Istanbuler Mitteilungen 62 (2012), 341 - 367. In this publication, a Theodosian date of transfer and reidentification is preferred.

120 The origins of the later identifications made are discussed in R.H.W. STICHEL, Bellerophon oder Joshua - zur vermeintlichen Missdeutung spätantiker Kaiserstatuen Konstantinopels in byzantinischen Quellen, in R. Harreither (ed.) Frühes Christentum zwischen Rom und Konstantinopel. Vienna 2006, 723-730. ANDERSON, Antiquarians (as footnote 97 above), comments on both identifications as well, but moreover offers a convincing explanation why the rider statue was no longer identified as a late antique emperor based on close reading of relevant passages in the Patria and Constantine of Rhodes. The statue and literary sources referring to it are mentioned in BASSETT, Urban image (as footnote 1 above), cat. no. 117.

121 (Historia 643, 649)

122 Similar identifications are already present in the Patria Konstantinupoleos 2.47; DAGRoN, (as footnote 1 above), 130, 135, 146; A. BERGER, Untersuchungen zu den Patria Konstantinupoleos. Poikila byzantina, 8. Bonn 1988, 326. As the Patria is a compilation of older sources, it is likely the identification is still older than the tenth century. STICHEL, Bellerophon (as footnote 120 above), 728, suggests the reidentifications of both Bellerophon and Joshua go back to associations between them and late antique emperors, made in late antique imperial panegyrics. 123 Stichel, ibid., 725-726; see now also ANDERson, Antiquarians (as footnote 120 above). 
the left hand holding a globe is somewhat puzzling in either case. ${ }^{124}$ Both identifications are based on a single aspect that hardly seems meaningful today.

Interestingly, the conclusion that one 'recognizable' element in a statue was enough to make a new identification alluring and convincing, is matched by conclusions reached by Richard Krautheimer concerning medieval architecture in his 1942 article "Introduction to an 'Iconography of Mediaeval Architecture"”. Based on a comparison of tenth- and eleventh-century 'copies' of the Holy Sepulchre, he found that, again to modern eyes, there was both an "inexactness in reproducing the particular shape of a definite architectural form" and a "peculiar lack of precision in medieaval descriptions not only of architectural patterns but of all geometric forms". ${ }^{125}$ With a wealth of architectural remains but also associated literary and related iconographic sources at his disposal, Krautheimer was able to infer that the minds of medieval viewers were indeed tuned to specific elements rather than the whole architectural prototype. Even though they transferred measurements, numbers and forms in splendid isolation and combined them with entirely new features in their new context, these single elements always remained representative of the original building. ${ }^{126}$ In some cases, the content and meaning of the original were so paramount that the mere dedication of a building (its new 'label' so to speak) was sufficient to turn it into a 'copy', even if the two physically had nothing in common. ${ }^{127}$ These, to us peculiar, manners in which 'recognition' of the Holy Sepulchre and in particular of the Anastatis Rotunda was achieved in medieval churches as well as in late antique and medieval iconographic representations, runs parallel to what we have seen for the ways in which statues were reidentified: a selection of one or more essential elements, which could differ from the ones modern viewers value most, enables identification.

Finally, before we turn to material evidence for Christian statuary, it is worthwhile repeating that statues could be simultaneously identified in multiple ways. As such, the rider statue on the Forum Tauri could be seen as both Joshua and

124 STICHEL, Bellerophon (as footnote 120 above), 725-726.

125 R. KRAUtheimer, Introduction to an 'iconography of mediaeval architecture'. Journal of the Warburg and Courtauld Institutes 5 (1942), 1-33, here 7.

126 In the case of the Holy Sepulchre, there was for instance a focus on the numbers of the eight piers supposedly present in the original Anastasis Rotunda or the twelve columns described by Eusebius as surrounding the apse of the Constantinian basilica. The imitation of either one or the other in medieval buildings was apparently sufficient to produce a 'copy' of the original sanctuary, regardless of the architectural form of the building they appeared in; see KraUtheIMER, Introduction (as footnote 125 above), 10-11.

127 Krautheimer, ibid., 16-20. 
Bellerophon by some and was still an imperial rider statue to others. ${ }^{128}$ Likewise, the introduction of a new identification could be highly contentious. Although I do not know of any literary reference pertaining to a contested reidentified Christian statue, contemporary passages do speak of gods and goddesses 'misidentified' as personifications or secular individuals. Zosimus thus comments on the rebranding of a statue of Rhea as the Tyche of Constantinople in orans pose, achieved in this case with minor physical alterations. ${ }^{129}$ The Parastaseis explicitly refers to the existence of contemporary competing opinions regarding a female seated statue in the Hippodrome. ${ }^{130}$

Disparate identifications, as in the past, may have reflected a different personal background or differing levels of knowledge, but also may have favoured personal observation and visual prompts over tradition or vice versa. ${ }^{131} \mathrm{~A}$ more in-depth study of this phenomenon, though obviously strongly related to the current topic, lies outside the boundaries of this article. When reviewing the material evidence in the following sections of this article, it is, however, important to be aware that assorted stories circulated among citydwellers and visitors, most of which were never written down, and that the Christian identification could be just one of many. ${ }^{132}$

128 Contentious and competing identifications occurred in previous centuries as well. Herodotus, for instance, mentions identifications of a Hittite relief figure in Karabel as the pharaoh Sesotris (the identity Herodotus himself prefers) and the Asian hero Memnon (RoJAS/SERGUEENKovA, Traces, as footnote 96 above, 154).

129 Zosimus 2.31.2-3.

130 Parastaseis $\S 61$, identified as Verina, wife of Leo I (474-491) or Athena. The story, with competing interpretations, is repeated in the Patria 2.78. See also LSA-107.

131 On the authorship of the Parastaseis, see AnDERson, Classified knowledge (as footnote 1 above). ANDERSON, Antiquarians (as footnote 97 above), contrasts the viewings of Theodosius' rider statue with that of Constantine of Rhodes. KInNEY, Horse (as footnote 3 above), 385 is able to distinguish between opinions expressed by pilgrims, locals and the clergy.

132 Although outside of the scope of this article, the fact that the opinions of ordinary citydwellers were not always received favourably by intellectuals is exemplified in a comment by al-Muqaddasi (d. 991) in his Ahsan al-Taqāsīm fì Ma'rifat al-Aqālīm, a major geographical work written around 985. Among the sights of the city of Hims (modern-day Homs), he lists a "figure of a man wrought in brass, standing on a fish which the four winds cause to rotate." Al-Muqaddasi continues: "About it many stories are told, but not to be believed. This town has suffered violent disorders, and is falling into ruin." After which he concludes: "The people there are stupid.” See: Al-Muqaddasi (d. 991), The best divisions for Knowledge of the Regions, trans. B. ColLins. Reading 2001, 133. I thank Edward Zychowicz-Coghill for pointing me to this passage. 


\section{Archaeological case-study: archangels at Sagalassos}

In view of the above, it is highly probably that some of the statues and reliefs still preserved today were at some point in their history viewed as Christian protagonists or scenes. None of these remains were mentioned as such in literary sources though, and none of them preserve epigraphic labels corroborating reidentification. Consequently, we have to rely on the statues themselves, a careful study of their find context and, when possible, an equally attentive reconstruction of their display context, as well as an investigation of the pertinent Christian iconographic repertoire. Due to word constraints, I will analyse one case-study in full as a matter of example, whereas other material remains will be discussed more succinctly in the following sections.

In late antique times, Michael, archangel and archistrategos of the heavenly army, was a highly popular intercessor between God and humankind. ${ }^{133}$ It was already mentioned how, according to Malalas, Constantine identified a cult statue as the archangel Michael. In keeping with the broader cult of angels, the cult of the archangel developed early in Asia Minor, notably in Germia and Colossae/ Chonae. ${ }^{134}$ Michael's popularity in Asia Minor is furthermore confirmed by the high number of inscriptions mentioning his name, especially in Pisidia, Phrygia, Asia and Galatia. ${ }^{135}$ At Sagalassos, a provincial town in Pisidia, the ruins of a bouleuterion were transformed into a church dedicated to St. Michael possibly in the second or third quarter of the sixth century. ${ }^{136} \mathrm{~A}$ concentration of inscriptions and graffiti mentioning the followers of Michael, the Michaelitai, were dis-

133 J.P. Rohland, Der Erzengel Michael, Arzt und Feldherr: zwei Aspekte des vor- und frühbyzantinischen Michaelskultes. Leiden 1977.

134 Colossae: F. NAU, Le miracle de Saint Michel à Colosses. PO 4 (1908), 542 - 562; U. HuTTNER, Early Christianity in the Lycus valley. Boston 2013, 372-382; PEERS, Subtle bodies (as footnote 107 above), 6-10, 143-151; Germia: MANGo, St. Michael (as footnote 66 above); PH. NiEwÖHNER/K. RHeIdT, Die Michaelskirche in Germia (Galatien, Türkei) - ein kaiserlicher Wallfahrtsort und sein provinzielles Umfeld. Archäologischer Anzeiger (2010), 137-160.

135 For the cult of the archangel, see J.C. ARNold, The footprints of Michael the Archangel. The formation and diffusion of a saintly cult, c. 300 - c. 800. New York 2013; P. NowAKowsKI, Inscribing the saints in late antique Anatolia. The Journal of Juristic Papyrology, Supplement, 34. Warsaw 2018, 196-199 lists inscriptions dedicated to Michael.

136 P. Talloen/B. Beaujean/J. Poblome, The 2015 control excavations in the BouleuterionBasilica of Sagalassos. Anadolu Akdenizi Arekoloji Haberleri 16 (2016), 119-128. 


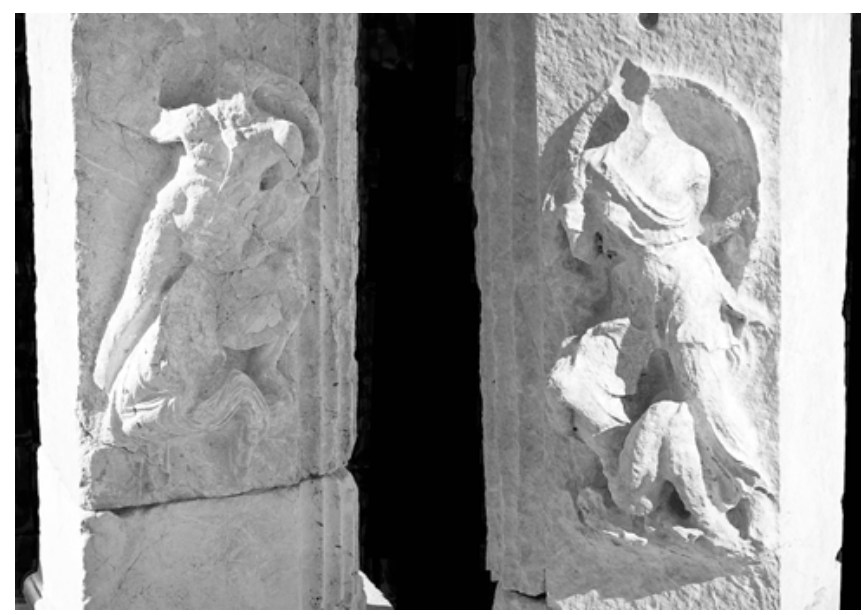

Fig. 3. Reliefs of Ares (left) and Athena (right) at the Bouleuterion Church of Sagalassos. Photos by the author.

covered in its immediate surroundings, on both ceramic patens and elements of architecture. ${ }^{137}$

At the time of the conversion, many of the building blocks and much of the original decoration of the bouleuterion were reused in the church's walls. Judging by the discovery of frieze fragments depicting helmets, shields and cuirasses in the debris of the church courtyard, some frieze blocks of the council house were reincorporated into the basilica's outer walls. ${ }^{138}$ They would indeed have made a fitting decoration for a church dedicated to the angel-warrior. Moreover, two piers from the original gallery were also recovered during excavations. One pillar bore a relief of a full-sized Ares, the other one of a full-sized Athena, with respectively a female and male prisoner at their feet (Fig. 3). ${ }^{139}$ Their find position in the debris indicated that they had been placed at the top of a monumen-

137 P. Talloen, Cult in Pisidia. Religious practice in southwestern Asia Minor from the Hellenistic to the Early Byzantine Period. Ph.D. diss., University of Leuven 2003, Sagalassos nos. 134 (SA93UA/222 = SEG XLIV, 1111), 135 (SA00B1/105), 136 (SA00B1/106), 137 (SA99B3/85). D. FEISSEL, Chroniques d'épigraphie byzantine 1987-2004. Centre de Recherche d'Histoire et Civilisation de Byzance. Monographies, 20. Paris 2006, no. 385.

138 M. Waelkens et al., The 1996 and 1997 excavation seasons at Sagalassos, in M. Waelkens/L. Loots (eds.), Sagalassos V. Report on the survey and excavation campaigns of 1996 and 1997. Acta Archaeologica Lovaniensia Monographiae, 7. Leuven 2000, 217-398, on 256-260; M. WAELKENS et al., The 1998-99 excavation and restoration season at Sagalassos. Kazı Sonuçlan Toplantılan 22 (2001), 159-180, on 164-165.

139 JaCobs/WaELKEns, 'Christians' (as footnote 34 above), 181-182. 
tal staircase connecting the church complex with the neighbouring Upper Agora, with the reliefs framing the entrance into the atrium and greeting visitors to the precinct.

The heads of both gods are missing. Had this decapitation been intentional, the reuse of the reliefs in this conspicuous location could cautiously have been considered a statement of the victory of Christianity over paganism. However, there are no clear marks on the stone to confirm deliberate decapitation and, in view of their overall poor state of preservation, the damage to the reliefs may just as well be the result of more natural processes. ${ }^{140}$ Narrative scenes such as these, with figures in full action who bear very few distinguishing attributes, generally were not targeted in Late Antiquity. ${ }^{141}$ Considering that they were probably still (largely) intact in the sixth century, it is far more likely that churchgoers looked favourably upon these reliefs and had given them a new identity. Since the Bouleuterion Church was dedicated to St. Michael, a new identification as archangels is very attractive. The billowing robes of Ares and Athena could have been taken for angels' wings, whereas the cowering figures, with their raised knees and arched bodies, are reminiscent of the serpents or dragons trampled in Christian triumphal iconography. ${ }^{142}$

Because of their perceived role as defenders, the archangels Michael and Gabriel were more frequently depicted as watchers and guardians at thresholds and gateways, for instance at the doorway of the late fifth-century basilica at Alahan (Fig. 4). ${ }^{143}$ Both of them have vanquished pagan enemies underneath their feet: Gabriel stands on "the back of a bull, below which is a male bust with head uncovered," whereas underneath Michael "busts of two female figures, each with a Phrygian cap on her head" were depicted. ${ }^{144}$ The iconography used here, with the angels Michael and Gabriel depicted static and frontally, was common for late antique depictions of archangels, but it was not the only way angels were

140 R. Turban, Des enfances de Bacchus à la Nativité, in V. Gaggadis-Robin/N. De Larquier (eds.), La sculpture et ses remplois. Actes des II ${ }^{\mathrm{es}}$ rencontres autour de la sculpture romaine. Bordeaux 2019, 17-19 discusses a comparable example where a relief depicting the birth of Dionysios was integrated as lintel into the Church of Corcolle. Up until the modern day it was viewed as the birth and infancy of Christ.

141 JACOBS, From production to destruction? (as footnote 6 above), 289.

142 A. Schaller, Der Erzengel Michael im frühen Mittelalter. Ikonographie und Verehrung eines Heiligen ohne Vita. Bern 2006, 53 - 57. The scenes show a certain resemblance to the calcatio colli (ritual trampling), which entered imperial triumphal iconography in Late Antiquity. 143 M. Gough (ed.), Alahan. An early Christian monastery in southeastern Turkey. Toronto 1985, 90, pls $21-22$.

144 Gough, ibid., 90, citing the original report by Michael Gough. 


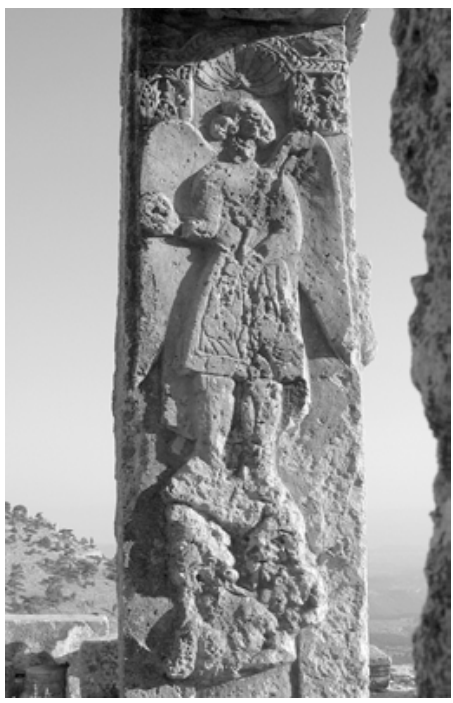

Fig. 4. The archangel Michael at Alahan. Photo (c) Göksu Archaeological Project.

imagined and, as usual, there was plenty of room for alternatives. ${ }^{145}$ In later medieval iconographic sources, the archangel Michael is often depicted in full armour, hovering over a vanquished enemy, often in the form of a serpent. This fully developed iconography of St. Michael slaying a demon or dragon shares a lot of resemblance to the Sagalassos reliefs, yet the earliest securely dated examples of this particular iconography of Michael date back only to around $700 . .^{146}$

It has been suggested that the more dynamic Michael iconography was based on the battle between Michael and Satan as described in the Book of Revelation 12:7-9. ${ }^{147}$ Other evidence suggests that these verses had an impact already in Late Antiquity. Eusebius for instance recounts how a painting of Constantine and his sons standing on top of a serpent pierced by a weapon was put on display in front of the imperial palace of Constantinople. Considering that Constantine had the image made in the aftermath of his victory over Licinius near the Michaelion of Chalcedon, the sanctuary dedicated to St. Michael con-

145 Glen Peers has argued that the metaphysical nature of angels made it very difficult to either describe or depict them. See PeErs, Subtle bodies (as footnote 109 above), esp. 19, 95-98, 185-193, G. PEERS, Apprehending the archangel Michael: hagiographic methods. BMGS 20 (1996), $100-121$.

146 SCHALLER, Erzengel Michael (as footnote 142 above), 62-63.

147 Ibid., $43-47$. 
structed by the emperor several years earlier, ${ }^{148}$ it is likely the emperor wanted to reference the war in heaven in an attempt to associate himself with St. Michael. ${ }^{149}$ The iconography of a Christian victor trampling a serpent became widespread in the following centuries, with examples in the palace mosaic in Sant'Apollinare Nuovo at Ravenna, and mid- to late-fifth-century gold emissions in both Ravenna and Constantinople, ${ }^{150}$ as well as on some late antique amulets and African Red slip ware, ${ }^{151}$ where it is presumably Christ who is trampling the serpent. In Laodicea in Phrygia, a pilgrimage ampulla was found with a depiction of either Christ or a saint treading on the snake/basilisk. ${ }^{152}$

Consequently, even though there is no evidence for newly created renditions of Michael in combination with the serpent in the sixth century and the Sagalassos reliefs showed much more movement than known contemporary images of the archangel, they fit into the existing iconography of Christian triumph. When the builders of the church came across these two reliefs in the debris of the bouleuterion, the presence of human-like figures and vanquished enemies at his/her feet may have been incentive enough to connect it to a biblical story that was most apt for a church dedicated to Michael. To modern eyes, not all details of the bouleuterion reliefs at Sagalassos are fitting for representations of archangels as demon slayers, even if the iconography was already known or developing around the middle of the sixth century. However, as discussed above, the aptness of an image was evaluated in a different way by

148 Eusebius, Vita Constantini 3.3.

149 R.F. Johnson, Saint Michael the Archangel in medieval English legend. Woodbridge 2005, 34. Alternatively, Constantine may have been referencing the mythic battle between God and the Leviathan described in the book of Isaiah (27:1).

150 By Valentinian III, Petronius Maximus, Majorian, and Severus at Ravenna in 425 - 465; by Marcian and Leo at Constantinople in 450-474. It became popular on Visigothic and Vandalic coinage during the mid fifth-century. See P. CouRCELLE, Le serpent à face humaine dans la numismatique impériale du Ve siècle, in R. Chevallier (ed.), Mélanges d'archéologie et d'histoire offerts à André Piganiol, 1. Paris 1966, 343 - 355; F. PANvini Rosati, La zecca di Ravenna. Antichità Altoadriatiche 13 (1978), 289-298, see 293-294; R. FARIoli CAMPANATI, Ravenna, Costantinopoli: aspetti topografico-monumentali e iconografici, in A. Carile (ed.), Storia di Ravenna 2.2.: Dall' èta bizantini all'età ottoniana. Venice 1992, 127 -157, on 141; E. A. ARSLAN, La zecca e la circolazione monetale, in: M. Mazza (ed.), Ravenna da capitale imperiale a capitale esarcale. Split 2005, 191-236.

151 Amulet: J. SPIER, An antique magical book used for making sixth-century Byzantine amulets?, in V. Dasen/ J. Spieser (eds.), Les savoirs magiques et leur transmission de l'Antiquité à la Renaissance. Florence 2014, 43 -66, see 48. African Red slip ware: J. HAYES, Late Roman pottery. London 1972, stamp no. 238, tentatively dated to the mid-sixth century or slightly earlier. 152 C. ŞıмşEK, Laodikeia (Laodicea ad Lycum). Laodikeia Çalișmalan, 2. Istanbul 2013, 491, fig. 724 . 
late antique and Byzantine viewers. Not all details had to match, far from it. One prompt sufficed to make the association and overlook nonconforming aspects.

\section{The importance of physical context}

Arguing for a Christian reidentification of the reliefs at the Bouleuterion Church at Sagalassos would not have been possible if their find context had not been carefully recorded and hence their display context at the entrance to a church atrium not reconstructed. Find and displays contexts of statuary are invariably instrumental when interpreting how it was viewed in its later life. When tracing Christian reidentifications in the material record, church contexts are an obvious starting point. Even though newly carved statuary has only in very rare occasions been found here, older items increase the total numbers. Next to the Sagalassos example, the statuary base and hence a statue reidentified as bishop Athanasios of Alexandria at a church in Echinos has already been discussed above. ${ }^{153}$

The best-known and probably also the most contested example of Christian reidentification, the famous preserved metope from the northwest corner of the Parthenon in Athens, likewise comes from a church context (Fig. 5). At an unknown moment, at the earliest when the temple was turned into a church dedicated to the Mother of God in the late fifth or sixth century, ${ }^{154}$ the metope sculptures of the east, west and north sides were defaced. They had carried mythological narrative scenes of Amazons (west), Giants (east), and the Sack of Troy (north), which seemingly lacked aspects that were offensive from a Christian point of view. By contrast, the Centauromachy metopes on the south side, the frieze on the inside of the peristyle and the temple's pediments were not targeted in the same manner, despite the latter being much more eye-catching and depicting loaded scenes, the birth of Athena on the east and the contest between Athena and Poseidon on the west. The preservation of much of the architecture and figurative decoration of the monument has been interpreted as a conscious decision fuelled by local patriotism to preserve a monument that was at the core

153 See also Turban, Enfances (as footnote 140 above).

154 For an overview of the literature on the later history of and changes to the Parthenon, see A. KALDELLIS, The Christian Parthenon: classicism and pilgrimage in Byzantine Athens. Cambridge 2009, 22-23, 31-40; R. OUSTERHOUT, 'Bestride the very peak of heaven': the Parthenon after antiquity, in J. Neils (ed.), The Parthenon: from antiquity to the present. Cambridge 2005, 293-329, especially 302-303; S. Alexopoulos, When a column speaks. The liturgy of the Christian Parthenon. DOP 69 (2013), 159-178, here 160-164. 


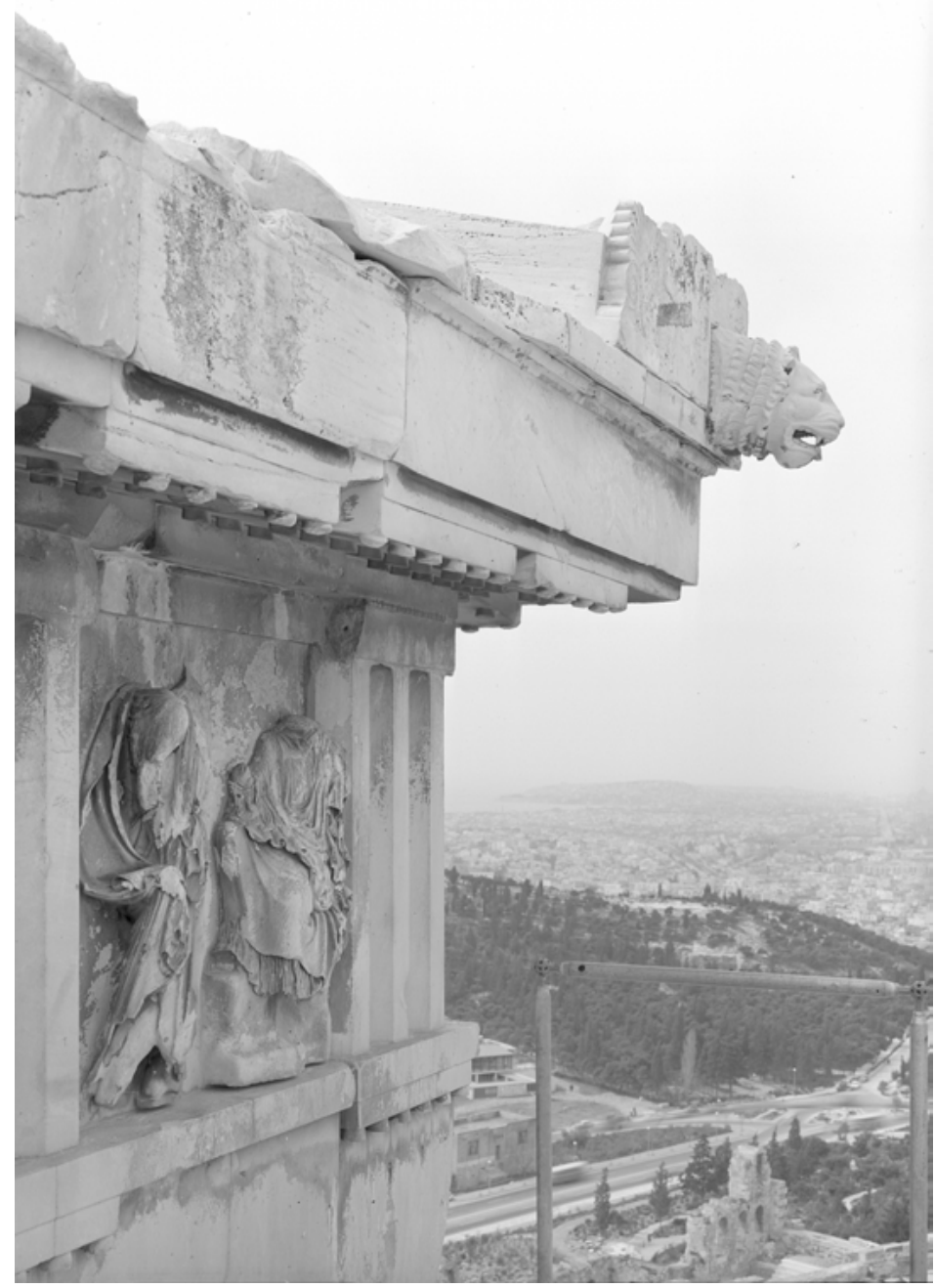

Fig. 5. Parthenon, Metope North 32 in situ (1962). Photo by E. Feiler, DAI Negative No. D-DAl-ATHAkropolis 2287. Image (C) DAl.

of Athenian identity. ${ }^{155}$ This makes the concerted effort to erase three-quarters of the metopes all the more puzzling. ${ }^{156}$

155 Kaldellis, Christian Parthenon (as footnote 154 above), 31-47. 
Only the metope at the western corner at the north side remains in a relatively good state of preservation. It is visible to a visitor of the Acropolis when facing the former Parthenon. The metope shows a figure of a woman, who approaches a seated and dignified female figure with a gesture of salutation. Modern scholars agree that this scene was originally intended to depict Athena with possibly the seated Hera. Yet, by the time the metopes were selectively mutilated, this relief may have been spared thanks to a 'recognition' of the scene as a Christian Annunciation, ${ }^{157}$ which would be a very fitting decoration for a church dedicated to the Mother of God.

Although a comparison of iconographic details is made difficult by later mutilations to the metope - the heads and some of the limbs were knocked off some observations can be made. ${ }^{158}$ If this relief indeed was reidentified, the prompt no doubt was the combination of seated female and approaching figure. In contemporary Annunciation scenes, which were already widespread both in monumental art and on small finds, items of jewellery, and in dress by the time the Parthenon underwent its transformation, ${ }^{159}$ Mary is generally seated on the right, while the angel approaches from the left, his announcement indicated by the raising of his right hand. ${ }^{160}$ Sixth-century Annunciation scenes

156 J. Pollini, Christian desecration and mutilation of the Parthenon. MDI, Athenische Abt. 122 (2007), 207 -228, esp. 214; N. BURKHARDT, The reuse of ancient sculpture in the urban spaces of late antique Athens, in Kristensen/Stirling, Afterlife (as footnote 39 above), 118-149 on 146-147. B. Anderson, The defacement of the Parthenon metopes. GRBS 57 (2017), 248 260 , contests a Christian attack altogether and favours a more pragmatic explanation for the different treatment of the reliefs.

157 G. Rodenwaldt, Interpretatio Christiana. Archäologischer Anzeiger (1933), 401-405; MANGo, Antique statuary (as footnote 1 above), 63-64; Ousterhout, Parthenon (as footnote 154 above), 293-329; K. A. SchwAB, Celebrations of victory: the metopes of the Parthenon, in Neils, Parthenon (as footnote 154 above), 159-197, see 165 - 166; KALDELLIS, Christian Parthenon (as footnote 154 above), 28, 40 - 42; R.R.R. SMITH, Defacing the gods at Aphrodisias, in B. Dignas/R.R.R. Smith (eds.), Historical and religious memory in the ancient world. Oxford 2012, 283-326, on 315-318; BURKHARDT, Reuse (as footnote 156 above), 147.

158 As this damage is different from that inflicted on the other metopes, it seems to date to a later moment in time. Pollini, Desecration (as footnote 156 above), 215, proposed that the mutilation occurred during the period of Byzantine iconoclasm, when the Christians also destroyed their own pictures. ANDERSon, Defacement (as footnote 156 above), 253-254 favours pragmatic reasons for the only partial defacement in the absence of evidence for reinterpretation. 159 For an overview of the development of the iconography, see M. LIDOvA, XAIPE MAPIA. Annunciation imagery in the making. IKON 10 (2017) 45-62; A.C.P. [PoE], Annunciation, in P.C. Finney (ed.), The Eerdmans Encyclopedia of early Christian art and archaeology. Grand Rapids 2016, 68-70.

160 D. Denny, The Annunciation from the right. New York 1977. 
are furthermore characterized by Mary holding up her right hand, parallel to the gesture made by the goddess originally depicted in the relief. ${ }^{161}$ The clothes of the standing goddess were similar enough to the typical angel's dress of tunic and cloak. The waving folds may even have functioned as stand-in wings. Finally, as at Sagalassos, also at Athens there was even a connection between the dedication of the church - to the Mother of God - and the imagery.

Even for more generic statuary, its find and supposed display context within a church can make a Christian identification a very alluring option. For instance, a head of Zeus or Asclepius found in a fifth-century context in the Church of St. Theodore at Gerasa is difficult to explain without turning to this hypothesis. ${ }^{162}$ Or what to think of a cross-marked black porphyry female head dated to the second or third century found in the pilgrimage centre of Abu Mina outside Alexandria? ${ }^{163}$ As remarked by Troels Kristensen, Abu Mina started to develop into a pilgrimage centre only in the fourth century, the pilgrimage industry being its sole reason for existence. Considering the Christian character of the site and the fact that the head must have been brought from elsewhere, a Christian reidentification and new purpose become very possible. ${ }^{164}$

Furthermore, a Christian identification of statuary is alluring also outside churches proper, in associated ecclesiastical buildings and structures. The presence of winged females-made-into-angel-iconography in the mid-Byzantine bishop's palace at Aphrodisias has already been discussed. Another example deserving of mentioning are the reliefs applied above the so-called Gate of Persecution on the Ayasoluk Hill at Ephesus, which because of their particular location may even have been intentionally polysemic. When the Basilica of St. John was surrounded with a fortification wall, probably around the time that the Justinianic church was built, its main gate was adorned with reused reliefs of third-century date, recovered from sarcophagi from one of the city's necropolises. ${ }^{165}$ The dec-

161 LIDOva, XAIPE MAPIA (as footnote 159 above), 52-53.

162 Amman, Jordan Archaeological Museum inv. J 2212. A.B. СooK, Zeus. A study in ancient religion 3.2. Appendixes and Index. Cambridge 1940, 1196-197 suggested it was reinterpreted as Christ. See also Th.M. WeBER, Gadara - Umm Qes. Untersuchungen zur Topographie, Geschichte, Architektur und der bildenden Kunst einer "Polis Hellenis" im Ostjordanland. Wiesbaden 2002, 487, cat. no. C 5, Taf. 123b.

163 T.M. KRISTENSEN, Miraculous bodies: Christian viewers and the transformation of 'pagan' sculptures in late antiquity, in Poulsen/Birk, Patrons (as footnote 81 above), 31 -66, see 54 cat. A7.

164 Kristensen, Miraculous bodies (as footnote 163 above), 42.

165 The construction date of the walls and the gate is disputed, see J. CRow, Fortifications, in Ph. Niewöhner (ed.), The archaeology of Byzantine Anatolia. From the end of late antiquity until the coming of the Turks. New York 2016, 90-108. The current excavators connect it with the 


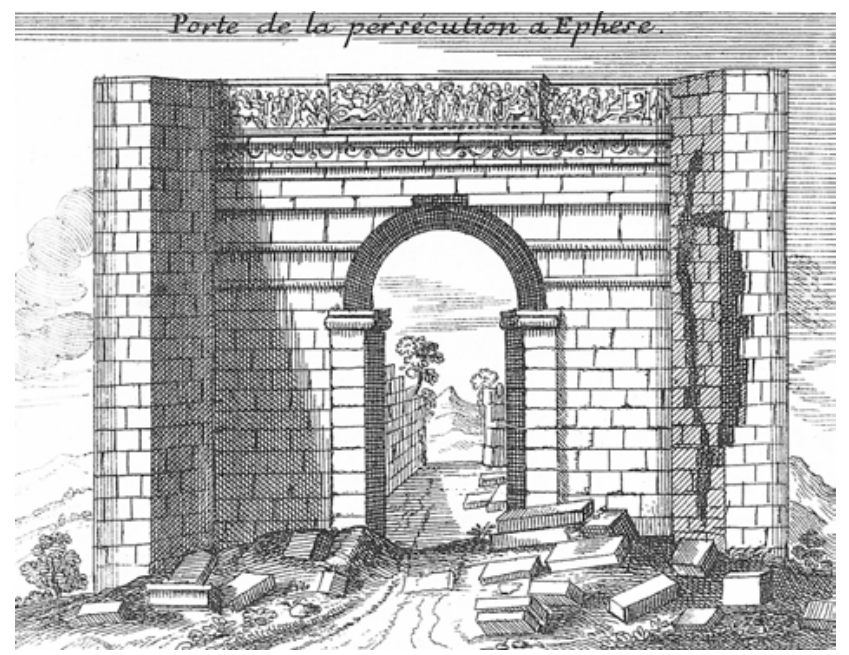

Fig. 6. Engraving of the Gate of Persecution, Ephesus. Image after Pitton de Tournefort (as footnote 166) Fig. after 518.

oration today consists of a series of slabs with vine scrolls and acanthus leaves and a scene with putti. Additional slabs are illustrated in eighteenth-century engravings (Figs. 6 and 7). ${ }^{166}$ They depicted scenes from the Trojan War, including Hector being dragged behind Achilles' chariot and Priam's supplication for the return of his son's body on the central panel, as well as Astinax being hauled away from a crying Andromache by Odysseus and the weighing of Hector's body on the right panel. ${ }^{167}$

Considering that the builders of the wall in all likelihood belonged to the (ecclesiastical) well-educated elite, they would have been familiar with the Illiad and the Trojan War. Homer indeed remained the most important author in the

Justinianic church: S. LADSTÄTTER, Ephesos from late antiquity until the middle ages. An archaeological introduction, in S. Ladstätter/P. Magdalino (eds.), Ephesos from late antiquity until the late middle ages. Vienna 2009, 11-72, here 55.

166 They were removed in the early nineteenth century and transported to England. Today, they can be viewed in Woburn Abbey, Bedfordshire, England (E. Angelicoussis, The Woburn Abbey collection of classical antiquities. Mainz 1992, 79-80 with further references). They were illustrated in their original location by J. PITTON DE TOURNEFoRT, Relation d'un voyage du Levant, fait par ordre du Roi, contenant l'histoire ancienne \& moderne de plusieurs isles de l'Archipel, de Constantinople, des Côtes de la Mer Noire, de l'Armenie, de la Georgie, des frontieres de Perse \& de l'Asie Mineure. Amsterdam 1718, Lettre XXII.

167 Angelicoussis, Collection (as footnote 166 above), 80-83, for an elaborate description. 


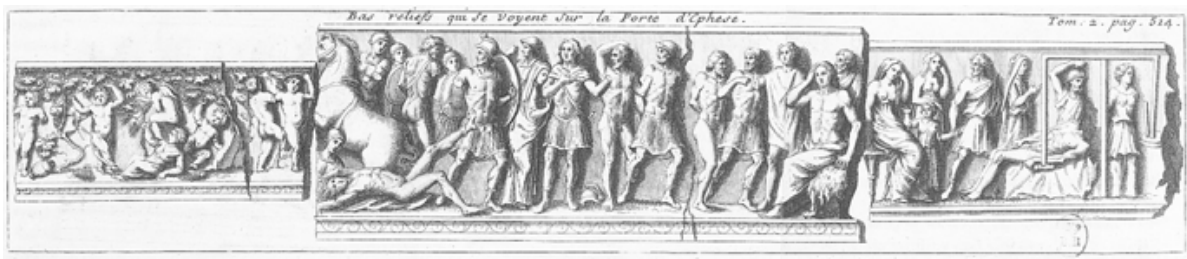

Fig. 7. Engraving of the Reliefs of the Gate of Persecution, Ephesus. Image after Pitton de Tournefort (as footnote 166) Fig. after 514.

school system long until after these walls were built. ${ }^{168}$ It is thus likely that the reliefs were still recognised as depicting the fall of Troy when they were moved to their new position above the gate. Yet, their location above the main entrance of one of the most important pilgrimage centres of the Byzantine world means that they also lent themselves particularly well to a Christian viewing. ${ }^{169}$ Pilgrims visiting the site, as well as the majority of local Ephesians, had not had the same education. To them, the much more familiar world of martyrs and saints would have come to mind on this saintly site. Even though the earliest references to the presence of a scene of martyrdom on the gate and the ensuing toponym 'Gate of Persecution' date back only to the later seventeenth century, the origins of this particular viewing therefore probably go back much further in time. ${ }^{170}$

A final example confirms once more why a good recording of find circumstances and reconstruction of display context are absolutely essential in arriving at an interpretation of reidentification. Ajootian in an article of 2000 describes a partially preserved Roman table leg in the form of Hermes Dionysophoros. The find location of the support in the debris of a Frankish structure at Corinth, together with its badly weathered right side, fuelled the hypothesis that it had been immured in an external wall of a room associated with a Frankish funerary

168 A. Markopoulos, Education, in R. Cormack/J.F. Haldon/E. Jeffreys (eds.), The Oxford Handbook of Byzantine Studies. Oxford 2008, 785 -795, see 788.

169 A. PÜLz, Das Stadtbild von Ephesos in byzantinischer Zeit, in F. Daim/S. Ladstätter (eds.), Ephesos in byzantinischer Zeit. Mainz 2011, 51-81, here 77-78. All buildings within the fortification were connected to the pilgrimage centre (LADSTÄTTER, Ephesos, as footnote 165 above, 247).

170 T. SмIтH, Remarks upon the manners, religion, and government of the Turks. Together with a survey of the Seven Churches of Asia as they now lye in their ruines: and a brief description of Constantinople. London 1678, 244; J. Spon / G. Wheler, Voyage d'Italie, de Dalmatie, de Grece, et du Levant, fait aux années 1675 et 1676. Amsterdam 1679, 246 mention that some of the locals saw a scene of martyrdom, and others the fall of Troy, but themselves refrain from making any identification. 
chapel and thus exposed to the elements for quite some time. ${ }^{171}$ The religious nature of the building complex in which the statuary was reused, like at Sagalassos, prompted Ajootian to suggest a Christian identity. More specifically, the iconography of an adult carrying an infant, heads close together, in the twelfth and thirteenth century was reminiscent of St. Christopher carrying Christ in the guise of a baby. ${ }^{172} \mathrm{~A}$ three-dimensional image of St. Christopher, patron saint of travellers, would have been a very apt decoration for a chapel associated with what may have been a complex intended to offer accommodation to pilgrims. ${ }^{173}$

\section{Applying Christian identifiers?}

So far, cross-marked statues have barely featured in this article. ${ }^{174}$ In conjunction with the application of a new name label, one would expect that a reidentification could also have been made permanent by a more general marker of Christian identity. However, reidentifications and cross-additions cannot simply be equated. The action of applying a cross or multiple crosses to a statue could have served quite different purposes, including exorcism and general updating, bringing statues into the Christian world and ensuring their continued survival and display. ${ }^{175}$ To establish that cross marking sealed reidentification, we need information on the display and use contexts of cross-marked statues and reliefs,

171 A. Ajootian, A Roman table support at ancient Corinth. Hesperia 69 (2000), 487 -507, see $487-490,502$.

172 Ibid., $502-503$.

173 For a discussion on the function of the building in Byzantine and Frankish times, see C. K. WiLliams II / O. H. ZeRvos, Frankish Corinth: 1992. Hesperia 62 (1993), 1-52, on 9-12; C. K. Williams II/ O. H. Zervos, Frankish Corinth: 1993. Hesperia 63 (1994), 1-56, on 24-26; C. K. Williams II / O. H. Zervos, Frankish Corinth: 1994. Hesperia 64 (1995), 1-60, on 11-15; C. K. Williams II et al., Frankish Corinth: 1997. Hesperia 67 (1998), 223-281, on 237-239.

174 The two main discussions of cross-marked statues are A. DeLIVorRIAS, Interpretatio Chris-

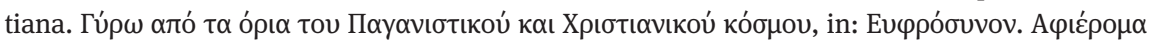

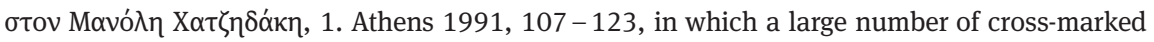
statues and reliefs from Greece have been assembled, and KrISTENSEN, Miraculous bodies (as footnote 163 above). I do think that both authors too readily considered the addition of a cross as a sign of reinterpretation, in the sense that the statue with the addition of the cross received an entirely new identity.

175 For an extensive discussion, see KRISTENSEN, Miraculous bodies (as footnote 163 above); I. JACoBs, Cross graffiti as physical means to christianize the classical city: an exploration of their function, meaning, topographical, and socio-historical contexts, in I. Garipzanov/C. Goodson/H. Maguire (eds.), Graphic signs of power and faith in late antiquity and the early middle ages. Essays on early graphicacy. Turnhout 2017, 175-221. 
which for most examples we do not have. Only occasionally was it recorded that cross-marked statuary had been found near a church building, as in the case of the porphyry female head at Abu Mina. ${ }^{176}$ In a few other cases, reidentification is certainly conceivable, for instance with cross-marked philosopher types. They include a portrait of Marcus Aurelius with the head covered as velatus from Italica and a stele from Andros. ${ }^{177}$ In the first case, a cross has been carved rather crudely on the left chest, in the second, an elaborate and carefully carved cross as well as the christogram IC XC and NIKA have been added behind a scene with a seated man teaching a young girl, not on the figures themselves, but almost as a certificate in the background. As described earlier in this article, the philosopher-teacher type could have served well as a stand-in body for Christ or a saint. Both the Marcus Aurelius statue and the teacher on the stele are visually quite similar to the bearded Christs appearing on fourth-century sarcophagi. Yet, without more information on their find and display contexts, all such suggestions remain highly conjectural.

In addition to crosses and sending a much clearer message, halos could be added to reliefs to enable future viewers to identify the subject as Christian saints more easily. ${ }^{178}$ Mango pointed to the halos added to some of the fragments of the Barbii monument framing the entrance door to the eleventh-century cathedral of S. Giusto at Trieste. ${ }^{179}$ In this case, the church context makes a Christian viewing undeniable. Late antique examples of added haloes must have existed, though once again we lack information on their display contexts. A stele in the Sparta Archaeological Museum had a halo carved around the head of the central figure. ${ }^{180}$ A standing male in military garb on a fragment of a second-century sarcophagus from Constantinople and now in the Louvre was provided with a halo at an unknown moment in time, thus transforming him into a military

176 Thus a portrait of a bearded man with a large and elaborate cross carved on its forehead was found in 1949 close to the fifth-century Basilica B at Philippi (KRISTENSEN, Miraculous bodies, as footnote 163 above, cat. A16). The head of a young man with a small and crude cross was found close to the Estauromenos church in Aigaleo in western Athens in the $1920 \mathrm{~s}$ (ibid., cat. A12).

177 Delivorrias, Interpretatio Christiana (as footnote 174 above), pl. 58, Kristensen, Miraculous bodies (as footnote 163 above), 39, 41-42, cat. no. B26 fig. 5 .

178 JENSEN, Understanding (as footnote 55 above), 112. The halo has a very long history that is not uniquely connected to Christianity, see M. ColLINET-GueRIN, Histoire du nimbe: des origines aux temps modernes. Paris 1961, 194-272 for the appearance of halos before Christianity, in the Graeco-Roman and eastern traditions and 273-421 for their appearance and usage in Christian visual culture.

179 MANGo, Antique statuary (as footnote 1 above), 64.

180 DelivorRias, Interpretatio Christiana (as footnote 174 above), 118, pl. 60. 
saint. ${ }^{181}$ An Apollo relief from Radheim in Germany had its/his genitalia removed and a halo added, again at an unknown moment. ${ }^{182}$

Nonetheless, as has already become clear, such physical alterations were not required for the allocation of a new identity. In the literary passages mentioned earlier, there is no mentioning of the paintings or statues having been marked by crosses or altered in any way.

\section{Rediscovery of statues}

Besides a specific prompt and the absence of a previous label identifying the statue, both of which have been discussed at length above, a third important condition for facilitating the possibility of reidentification is a change in cultural circumstances creating distance from the previous identity of a statue or relief. A new identity could thus be fashioned by taking the statue elsewhere, and creating geographic distance, or it could come into being because time elapsed between the previous identity of the statue and its new one. The statues taken by Constantine to Constantinople are an example of the first scenario. They may have fulfilled a certain role in their original location of display but were cut off from this by their physical relocation to Constantinople. Chronological distance in particular was apparently a vital factor, as the previous identity of the statue, the reasons for its dedication, and its significance could all be forgotten during the time that it was not actively in use. ${ }^{183}$ Chronological distance is sometimes signposted in literary sources by the fact that the statue was said to be 'rediscovered' by Christians. For instance, Philostorgius describes how the Christ statue at Caesarea Philippi was rediscovered after a period of neglect. The site of Rameses, where Egeria sees the statues of Moses and Aaron, had all but disappeared when she came across it. The bouleuterion at Sagalassos had been abandoned and was in ruins before the late fourth century when some

181 F. Baratte / C. Metzger, Catalogue des sarcophages en pierre d'époque romaine et paléochrétienne. Paris 1985, no. 190 bis; J. DuRAND, Byzance, l'art byzantin dans les collections publiques françaises. Paris 1992 -1993, no. 323; C. MANGo, L'attitude byzantine à l'égard des antiquités gréco-romains, in A. Guillou (ed.), Byzance et les images. Paris 1994, 95-120, on 114, Fig. 16.

182 B. SteidL, Welterbe Limes, Roms Grenze am Main. Munich 2008, $257-258$, fig. 275. The removal of genitalia does not preclude reidentification at all. For a nuanced discussion on the phenomenon, see PANAYIDES, Castrating (as footnote 87 above).

183 See also Rojas/Sergueenkova, Traces (as footnote 96 above) for shifts in identifications throughout time, from the Bronze and Iron Age to Ottoman travellers. 
of its reliefs were reused in the new fortification walls. ${ }^{184}$ At least 150 years had passed before the reliefs were turned around to greet visitors to the church dedicated to the archangel Michael. The Triconch House at Aphrodisias is thought to have been abandoned around the middle of the seventh century and reoccupied only in the late eighth or early ninth century, at which point the 'angels' in the peristyle courtyard were rediscovered. ${ }^{185}$ The builders of the fortifications on Ayasoluk Hill at Ephesus turned to funerary reliefs that were some 300 years old and possibly came from a cemetery that had been abandoned.

With the later examples, such as the Frankish reuse of the table support in the form of Hermes Dionysophoros, but also the much better studied reused reliefs at Merbaka or the Little Metropolis Church at Athens, the effects of the passing of time are even more obvious. ${ }^{186}$ Another illustration of providential 'rediscovery' comes from Rome: in 1551, a third-century headless statue was discovered by Pirro Ligorio at a church site near the Via Tiburtina. It began a new life as a representation of Bishop Hippolytus of Rome, a third-century theologian and martyr. ${ }^{187}$ Originally, the statue depicted a female - probably a seated muse. Presumably in the third century, the sides and back of the throne on which it was seated was used to inscribe Greek inscriptions: a calendar, a calculation of east, and, at the back, a list of books, some of them ascribed to Hippolytus. Consequently, when the statue was discovered, it was identified as Hippolytus, after which it was creatively altered and restored. Today, it is labelled 'Hippolytus' and is on display in the entrance hall of the Vatican Apostolic Library. Modern scholars rarely question the history of the statue itself and use it uncritically as a convenient illustration of the theologian. ${ }^{188}$ Such rediscoveries continue into the late modern period. For example, in 1817 a pharmacist living in Athens dug up a funerary stele. It was again recognized as a 'holy image' by the

184 L. LoOTS/M. WAELKEnS/F. DEPuYDT, The city fortifications of Sagalassos from the Hellenistic to the late Roman period, in M. Waelkens/L. Loots (eds.), Sagalassos V. Report on the survey and excavation campaigns of 1996 and 1997. Acta Archaeologica Lovaniensia Monographiae, 11B. Leuven 2000, 595-634, see 615-620; WAELKENS et al., 1996 and 1997 excavation seasons (as footnote 106 above), 231.

185 BERENFELD, Triconch house (as footnote 23 above), 224.

186 See footnote 3 above.

187 The statue is discussed in detail in P. NowAKowski, The Cult of Saints in Late Antiquity, E05385, http://csla.history.ox.ac.uk/record.php?recid=E05385, accessed on 20 April 2020.

188 For instance in G. BRAY, Early theologians, in P.F. Esler (ed.), The early Christian world. London/New York 2017, 565-586, here Fig. 29.1. 
locals, who bought the item and installed it in the narthex of the Church of the Megali Panagia. ${ }^{189}$

These instances of later rediscovery contrast strongly with the situation encountered at the Parthenon however. If we assume that the metope on the northwest corner of the building was indeed viewed as the Annunciation at least by some and that this reidentification took place already in Late Antiquity, then there was little or no time to forget the original identity of the protagonists, especially since Athens remained a centre for pagan intellectuals until the closing of its philosophical school in 529. ${ }^{190}$ As already mentioned, competing identifications were common and the Christian one may simply have been pushed through in this case. It may even be that these particular circumstances - the lack of chronological or geographical distance to ease an actualisation of identity and contemporary rival identities - led to the destruction of the other metopes. Whereas the reidentification of the remaining relief as an Annunciation has found relatively wide acceptance, we may gravely underestimate its importance in the history of the building and its potential to influence late antique decision making. Its preservation is generally considered an impromptu side-effect of a mutilation campaign targeting the other metopes. ${ }^{191}$ I would like to suggest that the reidentification of the 'Annunciation' metope, which as by divine providence was placed at the most visible corner of the monument, was made a priori and prompted the destruction of the other reliefs on the north, east and west sides, whilst leaving the much less visible south side. When it was decided to convert the Parthenon into a church dedicated to the Mother of God, local patriotism safeguarded the pediment sculptures, but the change in ownership was propagated through the highlighting of one relief with a scene central to the worship of the Mother of God, which only worked if it was not lost amidst other reliefs. In other words, the preservation of this one relief may not have been coincidental, but a clearly intended objective, whereas the destruction of the Parthenon's metopes with their fairly inoffensive mythological subject matter was not the goal, but a necessary corollary.

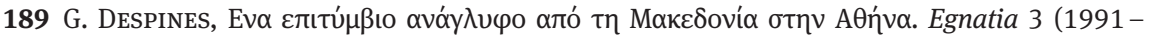
1992), 57-70, see 62-66; ANDERSon, Defacement (as footnote 156 above), 254, note 17. 190 E. J. WATTS, City and school in late antique Athens and Alexandria. The Transformation of the Classical Heritage, 41. Berkeley/Los Angeles 2006, 128-142.

191 Either because it was decided there and then that it would be a useful Annunciation or, according to ANDERSON, Defacement (as footnote 156 above), 253-54, because it was too difficult to deface it in the same thorough manner. 


\section{Conclusion}

In many cities in the Eastern Mediterranean, classical statuary and reliefs survived until the end of Antiquity and sometimes beyond. Rather than simply remaining puzzled over continuity of classical iconography, from time to time even integrated into church contexts, and rather than constructing complicated narratives of religious triumphalism, I have argued that we need to consider Christian reidentification as an additional explanation for the continued preservation of statuary. Even though examples discussed in this article will always remain hypothetical, the totality of literary, epigraphic and archaeological evidence testifies to the fact that Christians at times used statues to give shape to their celebrities and heroes.

Assigning new identifies to statues was not purely a Christian prerogative, but part of a much wider and much older phenomenon whereby statues and other kinds of depictions were continuously updated to changing circumstances. The practice acquired an additional Christian facet during the reign of Constantine at the latest, with the emperor himself apparently a participant in assigning both Christian and alternative secular identities. Christodorus' ekphrasis of the baths of Zeuxippos gives us a hint of how widespread the phenomenon was in Constantinople. In the newly established capital of the Empire, there was ample opportunity for updated identifications, as statues were brought from elsewhere in the empire often without their bases. Separated from their original cultural circumstances and accompanying inscriptions, it became possible to assign them new personalities and meaning, not limited to but certainly including Christian ones. As opposed to newly carved Christian statues and reliefs, the phenomenon of Christian reidentification was not limited to an early age of experimentation but continued throughout late antique and Byzantine times and far beyond.

Several conditions for reidentification have been identified in this article: the absence of an identifying label, geographical and/or chronological distance separating a statue from its original context of display, and the presence of a specific attribute or characteristic that became the prompt for reidentification. In some cases, a Christian identification was easy since the iconography of certain motifs, such as the Good Shepherd or Christ as Teacher, was so similar to its classical predecessors that identification depended mainly on the religious conviction of the viewer and a Christian physical context, including association with other figures and scenes. In other cases, aspects unbefitting the Christian identification were overlooked. Consequently, many of the reidentified statues and reliefs discussed in this article were not textbook reflections of already existing 
and fixed iconographies, but creative reimaginations instigated by the 'recognition' of sometimes only one specific detail. In order to solidify the new identity of a statue and probably to ensure that it won out over other competing identifications, a new epigraphic label could be applied. Although the archaeological examples of reidentified statues discussed in this article are not attested to in literary sources, they further testify to the three conditions for reidentification.

Apart from Constantine 'recognizing' a statue of the archangel Michael, explicit testimonies for who was responsible for Christian reidentifications do not exist. I argued that local bishops played a significant role in the process. Faced with (unidentified) statues, they either repurposed them by relating them to familiar stories of the Christian past themselves, or, at the very least, they supported and helped spread such new identities, which became all the more convincing once they were corroborated by church authorities.

These new identities, Christian and others, cannot simply be categorized as mistakes but need to be appreciated for what they were: creative manipulations and modernizations of the cityscape, executed by populations who continued to value the medium of statuary. 